\title{
The in situ Glyptostroboxylon forest of Hoegaarden (Belgium) at the Initial Eocene Thermal Maximum (55 Ma)
}

\author{
M. Fairon-Demaret ${ }^{\mathrm{a}, *}$, E. Steurbaut ${ }^{\mathrm{b}}$, F. Damblon ${ }^{\mathrm{b}}$, C. Dupuis ${ }^{\mathrm{c}}$, T. Smith $^{\mathrm{b}}$, \\ P. Gerrienne ${ }^{\text {a }}$ \\ a Université de Liège, Département de Géologie, Paléobotanique et Paléopalynologie, Allée du 6 Août, Bâtiment B18, \\ B-4000 Liège, Belgium \\ b Institut royal des Sciences naturelles de Belgique (IRSNB), Département de Paléontologie, 29, rue Vautier, B-1000 Brussels, Belgium \\ c Faculté Polytechnique de Mons, Géologie Fondamentale et Appliquée, 9, rue de Houdain, B-7000 Mons, Belgium
}

Received 19 June 2002; accepted 6 March 2003

\begin{abstract}
Hundreds of silicified standing stumps have been discovered within a lignitic horizon in the middle of the Tienen Formation near Hoegaarden in northeast Belgium. The anatomical features of the fossil stumps, as those of the numerous silicified secondary xylem remains collected since the last century from this area, demonstrate that they all belong to a single taxodiaceous taxon. The stumps bear characteristics shared by Taxodioxylon gypsaceum and Glyptostroboxylon tenerum, but affinities with the latter appear closer. They are attributed to Glyptostroboxylon sp. Calibration of the sedimentological, stratigraphical and organic carbon isotope data reveals that these taxodiaceous fossil trees developed in a swampy lowland environment most probably during the Initial Eocene Thermal Maximum at ca. $55 \mathrm{Ma}$.
\end{abstract}

(C) 2003 Elsevier B.V. All rights reserved.

Keywords: Early Eocene; fossil wood; gymnosperm; Glyptostroboxylon; taphonomy; Belgium

\section{Introduction}

The Tienen Formation, occurring throughout northern Belgium and in the east of the Mons Basin (Steurbaut, 1998), has been intensively studied in recent years because of its position close to the Palaeocene/Eocene boundary (Steurbaut et al., 1999, 2000, in press). Its base, in the

* Corresponding author. Fax: +32-4-366-5338.

E-mail address: m.fairon@ulg.ac.be

(M. Fairon-Demaret). more proximal continental settings known as the Dormaal Sands, is extremely rich in remains of land mammals (Smith and Smith, 1996; Smith et al., 1999; Steurbaut et al., 1999; Smith, 2000). Records of land plant macro-remains from the Tienen Formation are relatively rare, and usually consist of secondary xylem fragments (Stockmans and Willière, 1934; Doutrelepont et al., 1997). Current palaeobotanical information is mostly based on palynological analyses (e.g. Roche in Steurbaut et al., 1999, and in Steurbaut et al., in press), providing a generalised, homogeneous picture of the vegetation. Noticeable excep- 


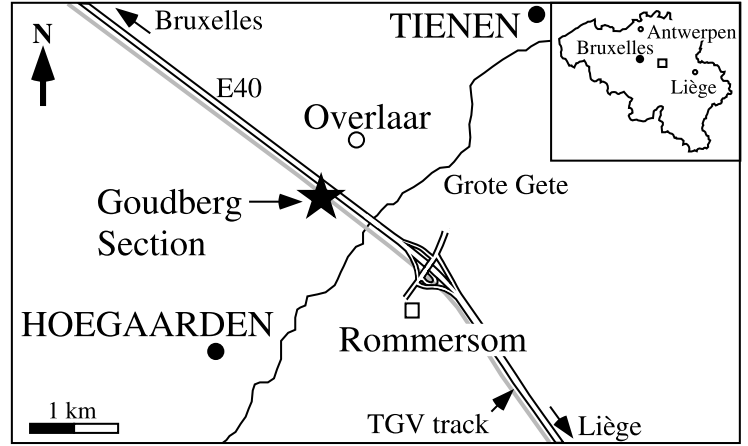

Fig. 1. Geographical location of the localities mentioned in the text, especially of the Goudberg Section (black star).

tions are the angiosperm leaf assemblage of Leval described by Marty (1907), which is in need of revision in the light of modern concepts of foliar morphologies, and the seeds and fruits recently described from Dormaal (Fairon-Demaret and Smith, 2002). Here we report the discovery of an exceptional apparently monospecific fossil forest at Goudberg-Hoegaarden, $3 \mathrm{~km}$ southwest of Tienen, in the Belgian province of Vlaams-Brabant (Fig. 1). Hundreds of silicified stumps are preserved in situ within a lignitic horizon (unit 5) in the middle of the Tienen Formation, in an area extending over more than one hectare.

\section{Geographical setting and lithological description}

The stumps were exposed during excavations for the new High Speed Train railway track at Goudberg-Hoegaarden, extending parallel to the Liège/Brussels E40 motorway $\left(50^{\circ} 47^{\prime} 27.4^{\prime \prime} \mathrm{N}\right.$, $04^{\circ} 54^{\prime} 06.1^{\prime \prime} \mathrm{E}$; altitude: $55 \mathrm{~m}$; Institut Géographique National Map 32/7-8: coordinates $x=187$, $y=164$; Figs. 1 and 4). An 8-m-thick section has been exposed (Figs. 2 and 3). Its upper part, down to the fossil-tree-bearing lignite, was seen in outcrop and the lower part in a series of 3-m-deep temporary trenches dug out at the railway track. This composite profile, known as the Goudberg Section, consists of nine distinct units, of which the lithological description is given in Fig. 2. The middle part of the section, including units $4-7$, is very complex and needs some more detail. Unit 4, made up of $0.5 \mathrm{~m}$ of leached whitish sands, locally includes quartzitic silcretes ('quartzite d'Overlaarlez-Tirlemont' of Ledoux, 1910). Occasional root casts with unidentifiable structure are observed perforating this thick but discontinuous white, massive sandstone layer with a bumpy upper surface. The embedding whitish sands are devoid of organic remains. Unit 5 consists of a $45-\mathrm{cm}$-thick layer of heterogeneous more or less lignitic deposits, enclosing the stumps and showing demonstrative compaction patterns. It includes in ascending order (Fig. 3): (1) 5.1a, a basal layer with dark lignite wrapping the bases of the trunks (Plate I); (2) $5.1 \mathrm{~b}$, small sandy lenses interstratified with lignitic layers towards the base, and with brown to grey clay towards the top; (3) 5.1c, grey-brown stratified clay with tiny black pieces of fusain; (4) 5.2, an intermediary clay layer with a more or less breccia-like texture, underlain by a white band progressively becoming grey-blue and darker, and towards the top interstratified with small, millimetre-thick lenses of brown clay; (5) 5.3, an upper light grey to brown clayey layer capped by 2-3 cm of dark brown clay with numerous root departures; and (6) $5.4,17 \mathrm{~cm}$ of blackish silt. Unit 6 consists of an about 45-cm-thick layer of brown sandy to silty mud with in the middle 10 $\mathrm{cm}$ of greyish clayey silt with a black organic-rich base. It is overlain by unit 7, consisting of a $5-\mathrm{cm}-$ thick layer of white clayey silt, locally finely laminated.

The succession is not always entirely preserved along the excavation front because of subsequent local erosion. Units 6 and 7, next to the upper 17 $\mathrm{cm}$ of unit 5 were missing in the eastern part of the excavation, reducing the thickness of the Tienen Formation by about $65 \mathrm{~cm}$.

\section{Stratigraphy and age of the fossil forest}

The stratigraphical interpretation of the different units of the Goudberg Section is exclusively based on lithofacies analysis, as the entire section is devoid of stratigraphically diagnostic microfossils (no dinoflagellate cysts and calcareous microfossils; a few pollen, spores and freshwater algae 


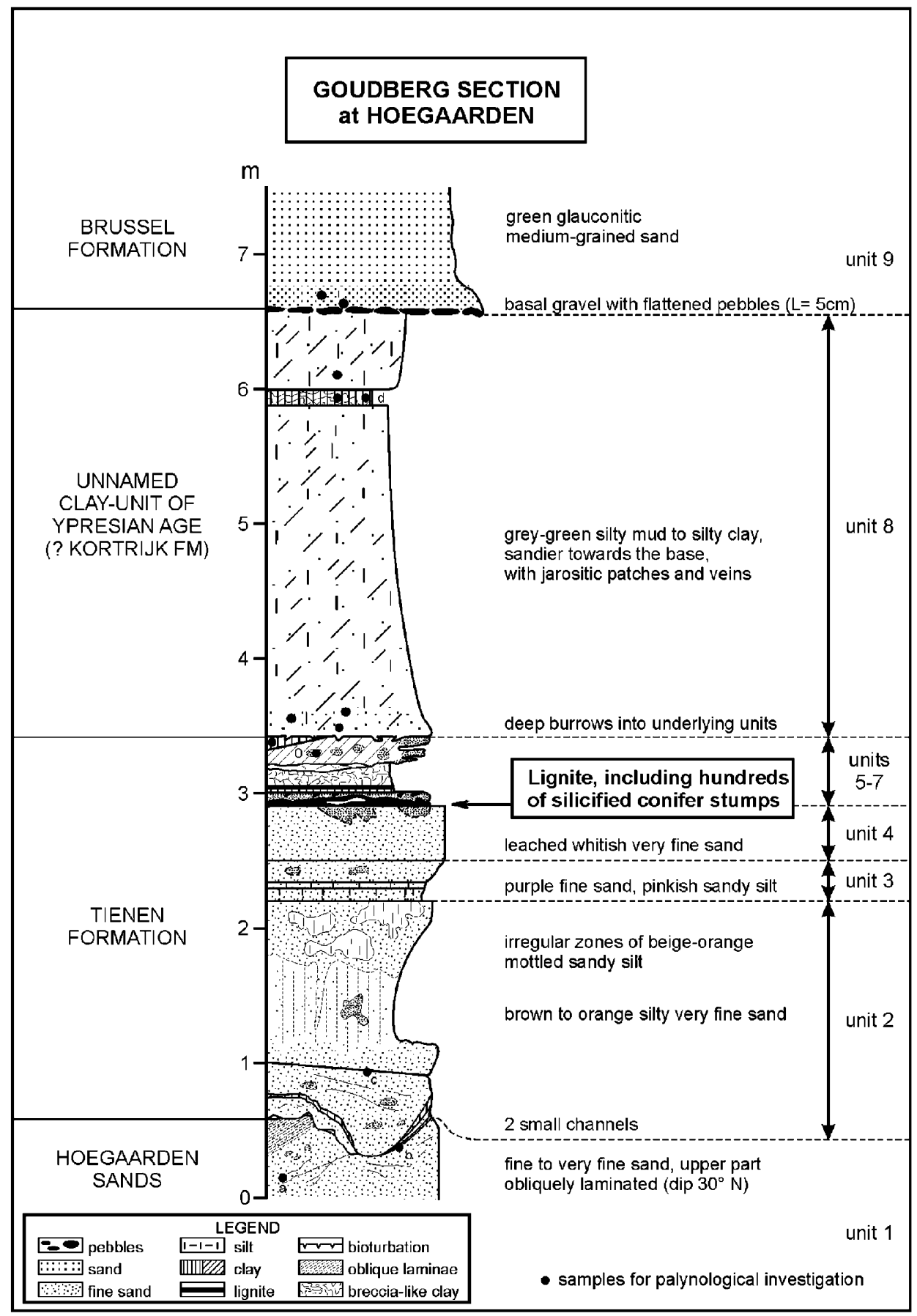

Fig. 2. Lithology of the Goudberg Section with position of the silicified stumps; compare with Fig. 3. 


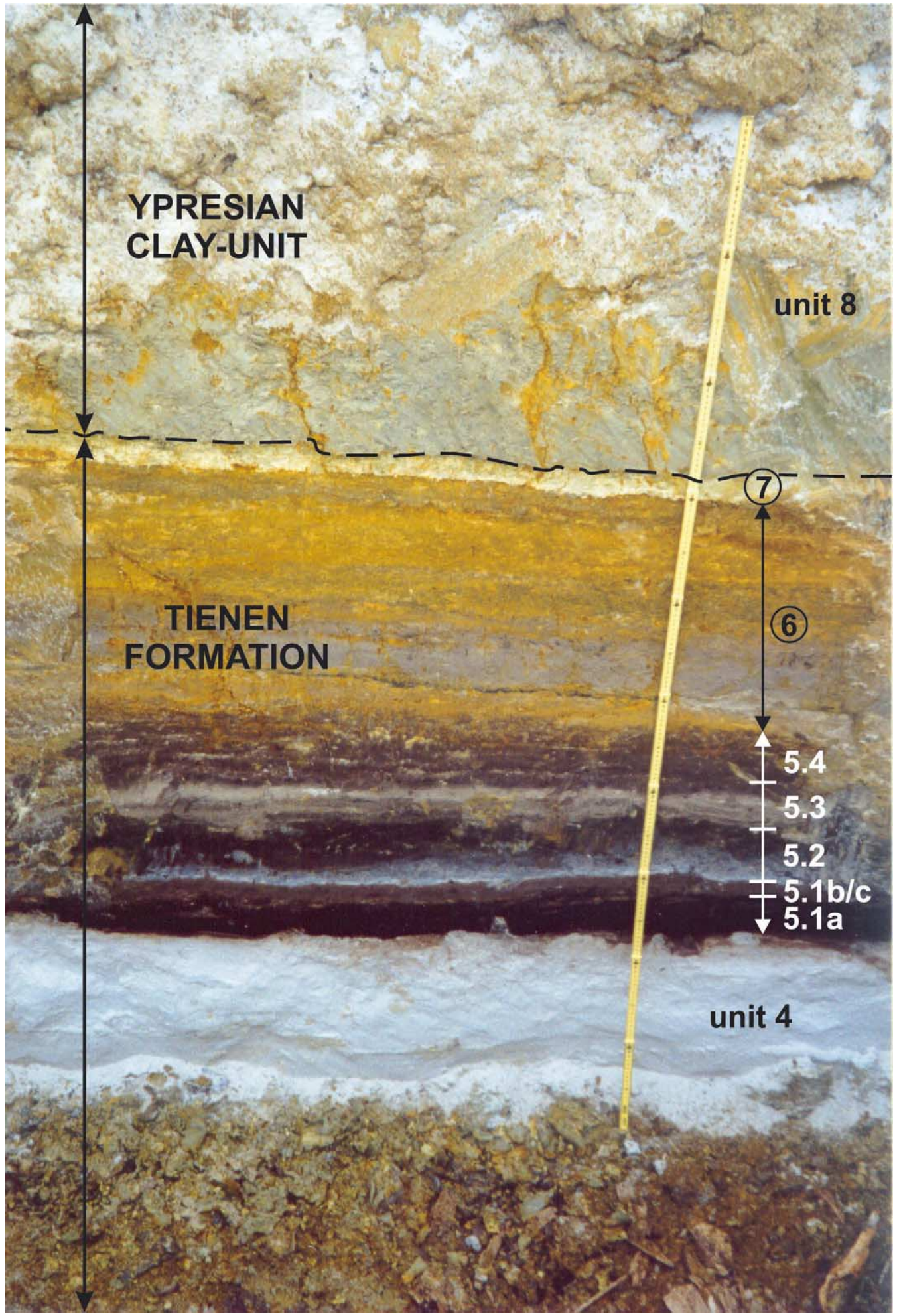

Fig. 3. Field picture of units 4-8 (photograph by Professor N. Vandenberghe). 
(Botryococcus sp.) were found in the top of unit 8; see Fig. 2 for location of samples). It includes identification of the lithofacies characteristics, trends and junctions, and relies on the lithostratigraphical classification of Steurbaut (1998), taking into account previous studies carried out in the Tienen area by Rutot (1887), Van den Broeck and Rutot (1894) and Gulinck (1948).

The glauconitic obliquely laminated sands of unit 1 are attributed to the Hoegaarden Sands, a not yet officially defined term for the estuarine sands occurring in the Hoegaarden area (Steurbaut, study in progress). These sands are sandwiched between the Upper Thanetian Grandglise Sands and the Tienen Formation. They are a lateral equivalent of the fully marine (infralittoral) Bois-Gilles Sand Formation, cropping out in the southwest of Belgium and calibrated with the middle part of Biochron NP 9 (Steurbaut, 1998), dated at 55.8 Ma (Berggren et al., 1995).

The overlying interval, ranging from unit 2 to unit 7, is marked by an essentially fluviatile depositional regime. Units 3 and 4 represent palaeosols. The white clean sands of unit 4 are due to intense leaching of a soil profile in a well-drained, warm, wet environment. Units 5 and 6 represent the peat swamp environment that developed as subsidence caused regional rising of the water tables, whereas unit 7 is thought to be lacustrine. The palaeoenvironmental characteristics of this essentially fluviatile interval, its heterogeneity and the presence of intraformational lignite refer to the Tienen Formation. Lignite beds are known to occur in many sections of the Tienen Formation (e.g. in northern Belgium in an essentially lagoonal context; see Steurbaut et al., in press) and its correlatives in northern France (the Mont Bernon Group; Dupuis et al., 1998; Magioncalda et al., 2001a) and in southern England (the Woolwich Formation; Bone, 1986; Ellison et al., 1994). In proximal settings (e.g. at Dormaal) these lignites overlie sandy deposits belonging to the Dormaal Sand Member (Steurbaut et al., 1999). This member, at the base of the Tienen Formation, is often rich in mammal remains, representing the well-known Dormaal mammal fauna (Steurbaut et al., 1999; Smith et al., 1999; Smith, 2000).
In the most complete settings of northwest Belgium (Knokke area), the Tienen Formation is unconformably overlain by the Zoute Silt Member, the lowermost member of the Kortrijk Clay Formation (Steurbaut, 1998; Moorkens et al., 2000). The latter is part of the Ypresian stratotype. The Zoute Silt Member, through calibration known to be deposited within Biochron NP 10, posterior to the well-known Apectodinium acme, is missing in the Goudberg Section. Instead, a clayey unit occurs (unit 8), which on the ground of its geometry and lithofacies may belong to the Kortrijk Clay Formation. The overlying unit 9, of which several metres are locally preserved, is incorporated in the Brussel Formation (Sintubin et al., 2000).

The lignite of the Goudberg Section in which the fossil stumps were found does not contain any biostratigraphical marker. However, its age can be reliably inferred from organic carbon isotope analysis. The isotope values measured in the Goudberg lignite present a trend towards more positive values from $-25.7 \%$ o to about $-25.0 \%$ o PeeDee Belemnite (Magioncalda, pers. commun.). The same isotopic trend and values are recorded at five stratigraphically distinct places in the Mont Bernon Group of the Cap d'Ailly Section in northern France, just below the lignitic complex $\mathrm{L} 1$, in its lowermost part (L1a), at its top (L1c), within unit SP3 and within unit SP4, respectively (Magioncalda et al., 2001a,b). However, comparison with the isotope curves of the Kallo and Doel boreholes, $75 \mathrm{~km}$ northwest of the Hoegaarden area (Steurbaut et al., in press), suggests that the third option is the most plausible one, and that the Goudberg lignite should be correlated with lignite L1c of the Cap d'Ailly Section and with the lignitic interval $\mathrm{L}$ in the middle of the Tienen Formation at Kallo and Doel. The pollen and spore records support this correlation. The lignitic interval encountered at Kallo and Doel and those from other localities in the vicinity of Hoegaarden (Loksbergen, Budingen) contain similar palynomorph associations, marked by the highest occurrence of Subtriporopollinites magnoporatus tectopsilatus, by the presence of Intratriporopollenites microreticulatus and I. pseudoinstrictus, and by the absence of Subtriporopollenites spissoexinus (Hauregard, 1999; Ostojski, 2001). As a conse- 

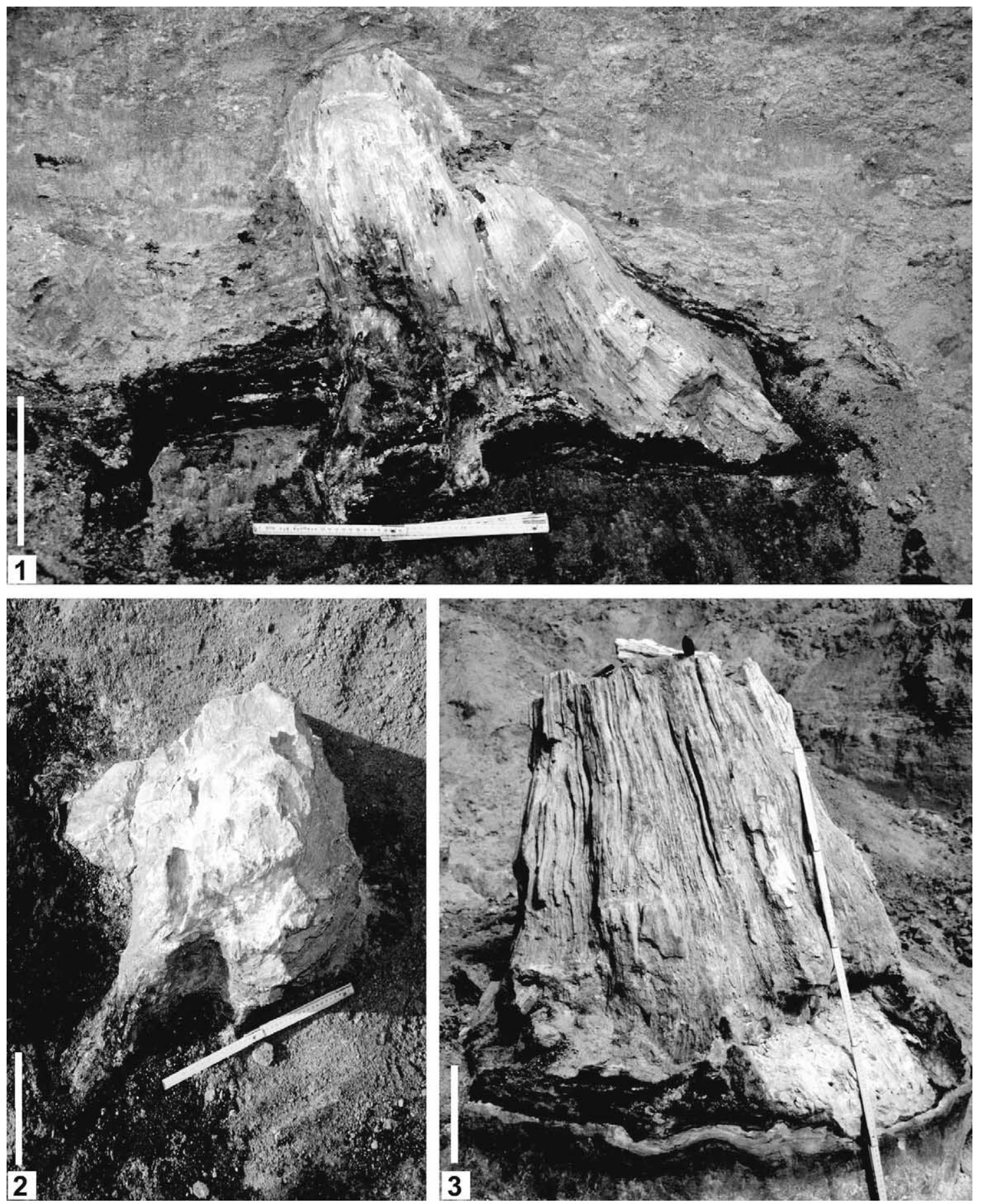
quence, these lignite levels are believed to be contemporaneous or only slightly different in age.

Carbon isotope shifts from $-26.0 \%$ to $-25.0 \%$ are known to occur within the organic Carbon Isotope Excursion (CIE) in terrestrial, lagoonal, as well as marine settings (Steurbaut et al., in press; Magioncalda et al., 2001a, and unpublished research). Estimates for CIE duration vary greatly (Norris and Röhl, 2000), although recent high-resolution studies point to a duration of ca. 84000 years, ranging from 55.50 to 55.41 Ma using the age model of Bains et al. (1999) and from 55.00 to $54.92 \mathrm{Ma}$ using the model of Bowen et al. (2001, fig. 7). The base of the CIE has recently been chosen as the criterion for the Palaeocene/Eocene boundary (Luterbacher et al., 2000). Integration of these data indicates that the fossil trees of Hoegaarden probably developed during the Initial Eocene Thermal Maximum (IETM, formerly LPTM) about $55 \mathrm{Ma}$, when climate was the warmest of the entire Cenozoic (Koch et al., 1992; Norris and Röhl, 1999). According to Godinot (2000), based on data from Besse and Courtillot (1991), the Hoegaarden forest was situated at a palaeolatitude of approximately $40^{\circ} \mathrm{N}$.

\section{Historical background}

Silicified pieces of secondary xylem have been known in the Tienen area since the middle of the nineteenth century (Lyell, 1852). Big stumps were encountered in the quarry of Overlaar (Fig. 1), located at about mid-distance between Hoegaarden and Tienen (Rutot, 1887), while extracting the 'Landenian' massive sandstone, and in a road section at Wommersom $10 \mathrm{~km}$ to the east (Rutot, 1887). At Overlaar, the stumps were observed in upright position in a bed of lignite over- lying white sands located above a sandstone layer. As early as 1887, Rutot discussed the origin of the 'fossil forest of Overlaar'. In his opinion it represented the remnants of an in situ forest that had been growing in a littoral, swampy environment. Quickly a controversy arose about the 'in situ' position of the 'fossil forest'. Stainier (1909) put forward several observations justifying the allochthonous character of the stumps that would have been transported by fluvial currents before deposition. He particularly pointed out the absence of appreciable lengths of anchoring organs, and the presence of big root departures only at the base of the stumps. He also noticed a relationship between the shape of the tree fragments and their orientation in the embedding matrix: cylindrical trunks, which are the longest, were found in horizontal position while the conically shaped ones with a wide, spreading base were found standing. As the centre of gravity of such conical stumps is lower than their centre of figuration, they could well have been carried upright in mudflows and have consequently been deposited upright. On the other hand, Ledoux (1910) argued that these stumps were never seen prostrate or gathered into irregular piles, one above another, as a consequence of flood rafting and accumulation. As the distances between adjacent stumps were similar to those observed in a present-day forest, he claimed that the fossil trees of Overlaar were autochthonous. Since that time, members of both 'schools' maintained their positions due to lack of new observations (Hauregard, 1999).

\section{Materials and methods}

The studied specimens, which have all been collected from the same horizon in the Tienen For-

Plate I.

1-3. Goudberg Section, Hoegaarden (Belgium), earliest Eocene. In situ trunks.

1. Lateral view of a specimen still partly embedded in the sediment, showing marked deflection of the lignite layer around the trunk base. Scale bar $=20 \mathrm{~cm}$.

2. Apical view of a trunk base with well-developed buttress-like roots. Scale bar $=20 \mathrm{~cm}$.

3. Lateral view of a large trunk base showing the usual $20-30^{\circ}$ dip towards the east. Note the thin underlying lignite layer. Scale bar $=20 \mathrm{~cm}$. 


mation, belong to three distinct groups. The first group is made up of 23 specimens from the Stockmans' collection of stumps and branches retrieved during the last century from the now disused Overlaar quarry, and preserved in the palaeobotanical collections of the Royal Institute of Natural Sciences at Brussels. The second one includes more than thirty isolated dispersed pieces of secondary xylem recently collected at and around the Goudberg Section, and more particularly along the motorway which runs parallel in places to the new railway track (Fig. 1). The tiny silicified pieces obtained while macerating the lignitic matrix are added to this second group. The third group consists of silicified secondary xylem fragments collected from six in situ tree bases at Goudberg.

Two areas about $200 \mathrm{~m}$ apart in southeast direction along the motorway were systematically dug out up to the standing stumps at the base of unit 5 (Fig. 4). The first one, rectangular in shape (Fig. 4A,C, 1), is $70 \mathrm{~m}$ long and $20 \mathrm{~m}$ wide. Some 74 irregularly distributed stumps and dispersed pieces of trunk were recorded (about 500 trees/ha). Additional stumps were noticed outside this area, indicating that many more are still embedded in the undisturbed surroundings. The second area, with a semicircular boundary, of which about 0.15 ha was excavated (Fig. $4 \mathrm{~A}, 2)$, demonstrated an irregular distribution of 67 stump and/or trunk remains. Nearby this second area (Fig. 4A, 3) the embedded stumps were carefully uncovered in an area of $7.5 \mathrm{~m}^{2}$ in order

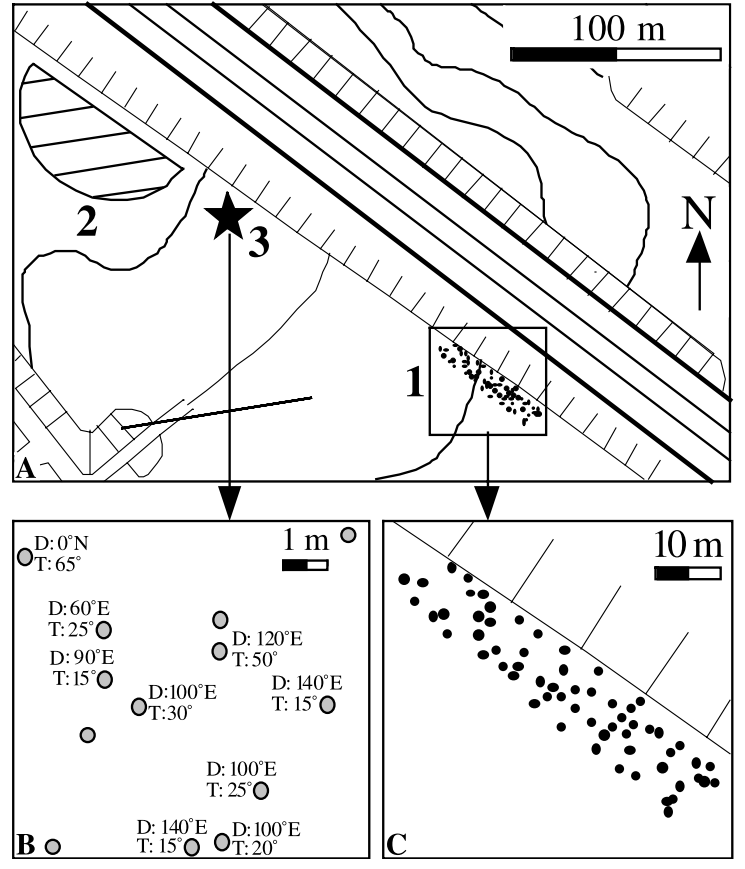

Fig. 4. (A) Position of the three areas, 1, 2 and 3, systematically excavated up to the standing stumps. (B) Detail of the position of the 13 stumps of area 3. Abbreviations: D, direction of inclination of each stump; $\mathrm{T}$, angle of inclination. (C) Detail of the irregular distribution of 74 stumps (black dots) in area 1.

to measure their height, diameter at the base and top, direction and angle of inclination, as well as the spacing between individuals (Fig. 4C).

The stumps from Goudberg share the same characteristics. They rest on a thin layer of lignite

Plate II. Transmitted light micrographs of thin sections of the secondary xylem Glyptostroboxylon sp. from the Tienen Formation, Belgium.

1-3. Transverse sections.

4-6. Longitudinal tangential sections.

1. General view; growth rings and false rings. Specimen IRSNB 67855. $\times 50$.

2. Detail showing the shape of the tracheids. Specimen IRSNB 67680. $\times 100$.

3. General view of secondary xylem devoid of false ring. Notice the distribution of the xylem parenchyma cells. Specimen IRSNB $67590 . \times 30$.

4. General view of the vascular rays. Specimen IRSNB $67680 . \times 85$.

5. Detail of a vascular ray biseriate on one row. Specimen IRSNB $67590 . \times 350$.

6. Uniseriate rays of various heights. Notice the small bordered pits on the tangential walls of the tracheids. Specimen IRSNB 67590. $\times 190$. 


interstratified with black clay, and are surrounded by a thin layer of dark and glossy lignitic clay. They are silicified, more or less conical in shape, truncated at the top which appears scalloped and crushed (Plate I, 1-3), and generally range between 60 and $100 \mathrm{~cm}$ in height. They stand upright, and most of them, when fully detached from the clayey embedding matrix, show a 20 $30^{\circ}$ dip towards the east (Fig. 4B; Plate I, 1,3). Their distal diameter usually ranges from 30 to 60 $\mathrm{cm}$, the biggest specimens reaching up to $80 \mathrm{~cm}$. The stumps are decorticated and an unknown thickness of the outermost wood layers is not preserved. The diameter of the trees at breast height (dbh; necessary for reporting stand basal area) could not be valuably estimated. The base of each upright stump is enlarged with buttress-like flanges (Plate I, 1,2). No attached roots have been observed penetrating the underlying layers for an appreciable length, and only the departure of sturdy, horizontal basal roots has occasionally been seen, spreading laterally from the enlarged base of the stumps. Several specimens are recorded lying in-between the standing stumps. These are trunk-like, cylindrical in shape but usually are dorso-ventrally flattened, being preserved over a longer length than the standing tree bases.

The wood was studied using conventional thin sections combined with observation of fractured fragments under the scanning electron microscope (SEM). A transverse thin section of every specimen was prepared, and when preservation appeared promising, tangential and radial sections were made. Light microscopy was performed us- ing the photomicroscope Reichert Polyvar. In addition, pieces of fractured silicified secondary xylem were prepared on stubs and gold-coated. Observation and photographs were made using a Jeol JSM-5800 scanning electron microscope. Pieces of lignite were also soaked in hot water with $\mathrm{Na}_{2} \mathrm{CO}_{3}$ added and the dark brown solution obtained was sieved. No remains of diaspores were preserved and only naturally macerated silicified fragments of secondary xylem were retrieved. These were also studied under the SEM.

Maceration of the lignite embedding the bases of the tree as well as of the clayey matrix was also performed using standard palynological procedures (Streel, 1965). No palynomorphs have been found in the samples of the Tienen Formation, including the lignite of unit 5 (see Fig. 2 for location). This is probably due to severe oxidation.

\section{Mineralogy of the fossil wood}

Any attempt at demineralisation of the in situ and dispersed silicified secondary xylem fragments was disastrous. Microdiffraction studies show that polycrystalline fine-grained quartz is the main component of the specimens, mixed with amorphous opal (Kuczumov et al., 1999). Quartz occurs both in cell walls and lumina, and very little, if any, of the original organic matter is still present. Apparently, the secondary wood pattern has not been lost to an appreciable extent during the transition from the opal-like to the microquartz structure.

Plate III. Transmitted light micrographs of radial thin sections of Glyptostroboxylon sp. from the Tienen Formation, Belgium.

1. A vascular ray, two cells high with 1-4 rounded, eroded pit apertures/cross-field. Notice the shape of the cross-fields. Specimen IRSNB 34865. $\times 350$.

2. An early wood vascular ray, four cells high; the marginal cells show four cross-field pits arranged in two tiers; the median cells show two, side by side, taxodioid to glyptostroboid pits. Specimen ULg I2. $\times 300$.

3. Glyptostroboid to taxodioid early wood cross-field pits. Specimen IRSNB $67590 . \times 300$.

4. Detail of the bordered pits on the horizontal walls of the tracheids. Specimen IRSNB 67590. $\times 870$.

5. $\quad$ Paired bordered pits. Crassulae are obvious. Specimen IRSNB 34865. $\times 350$.

6. Radial wall of a wood parenchyma cell. Specimen IRSNB 67642. $\times 870$.

7. Slightly knotted radial wall of a wood parenchyma cell. Specimen ULg I3. $\times 870$. 




\section{Taxonomy}

Family Cupressaceae Gray, nom. cons.

Subfamily Taxodioideae Endl. ex K. Koch

Genus Glyptostroboxylon Conwentz

Glyptostroboxylon sp.

\section{Description}

The characters of all secondary xylem specimens studied are distributed along a continuum of variation, and despite some apparent dissimilarity it was impossible to separate them into different structural entities. They are consequently interpreted as belonging to a single taxon, and described accordingly.

The secondary xylem is homogeneous and shows no normal resin canals (Plate II, 1,3). Despite the high number of specimens studied, no traumatic resin ducts were observed. Growth rings are clearly distinct (Plate II, 1-3), and of very variable width. Within the same specimen, some growth rings show a gradual early-to late wood transition, whereas others show an abrupt transition (Plate II, 1-3). False rings may occur, generally in the outermost part of a growth ring (Plate II, 1); their number and frequency are highly variable. Early wood tracheids of wide growth rings are generally hexagonal to more or less rounded (Plate II, 2,3). They are more quadrangular in the early wood of narrow growth rings (Plate II, 1), and are tangentially compressed in late wood. Early wood tracheids have a radial diameter of 24-56 $\mu \mathrm{m}$ (usually $40 \mu \mathrm{m}$ ) and a tangential breadth between 32-44 $\mu \mathrm{m}$ (usually 40 $\mu \mathrm{m})$. As a rule the tangentially broadest tracheids

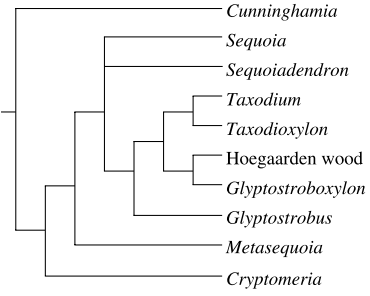

Fig. 5. Maximum likelihood phenogram stemming from a cladistic analysis using the characters listed in Table 1.

occur near the middle of a growth ring. The radial walls of early wood tracheids bear uniseriate to rarely biseriate opposite bordered pits, $14-17 \mu \mathrm{m}$ in diameter (Plate III, 1,4,5; Plate IV, 1). Crassulae are common (Plate III, 4,5). Bordered pit pairs have a well-developed torus which is scalloped (Plate III, 4,5). Their apertures are slightly elliptical. On the tangential walls of late wood tracheids slightly smaller uniseriate bordered pits, $12-15$ $\mu \mathrm{m}$ in diameter, are common (Plate II, 6).

Axial parenchyma is diffuse (Plate II, 2,3) or loosely grouped in tangential rows, 1 cell wide (Plate II, 1). In longitudinal sections the secondary xylem parenchyma cells are typically barrel shaped (Plate IV, 1). Brown to black deposits are frequent and usually obliterate the wall details (Plate III, 7; Plate IV, 1). The horizontal walls are thin (Plate IV, 5) and smooth, slightly knotted when pits are present (Plate III, 6,7). They never appear strongly beaded. Small rounded half-bordered pits occur on their vertical walls often arranged in two irregular, more or less parallel rows (Plate IV, 5).

Vascular rays are homocellular (Plate II, 4-6; Plate IV, 1,2). They are mostly uniseriate, ranging from 1 to 34 cells high, although typically only up

Plate IV. Scanning electron micrographs of fractured longitudinal radial plane of Glyptostroboxylon sp. from the Tienen Formation (Belgium). Specimen ULg I3.

1. General view with two vascular rays and two vertical rows of parenchyma cells. $\times 95$.

2. Detail of wide, rounded to oval, cross-field pits. Notice the outline of the cross-fields. $\times 490$.

3. Glyptostroboid cross-field pits (casts) irregularly arranged, up to five per cross-field. $\times 490$.

4. Variation in shape, size and arrangement of cross-field pits with a very narrow border. $\times 490$.

5. Detail of a wood parenchyma cell with small half-bordered pits. $\times 290$.

6. Detail of a vascular ray showing sparsely pitted (arrow heads) horizontal walls and occasionally, an enlargement at the junction between horizontal and vertical walls (small arrows). $\times 875$. 

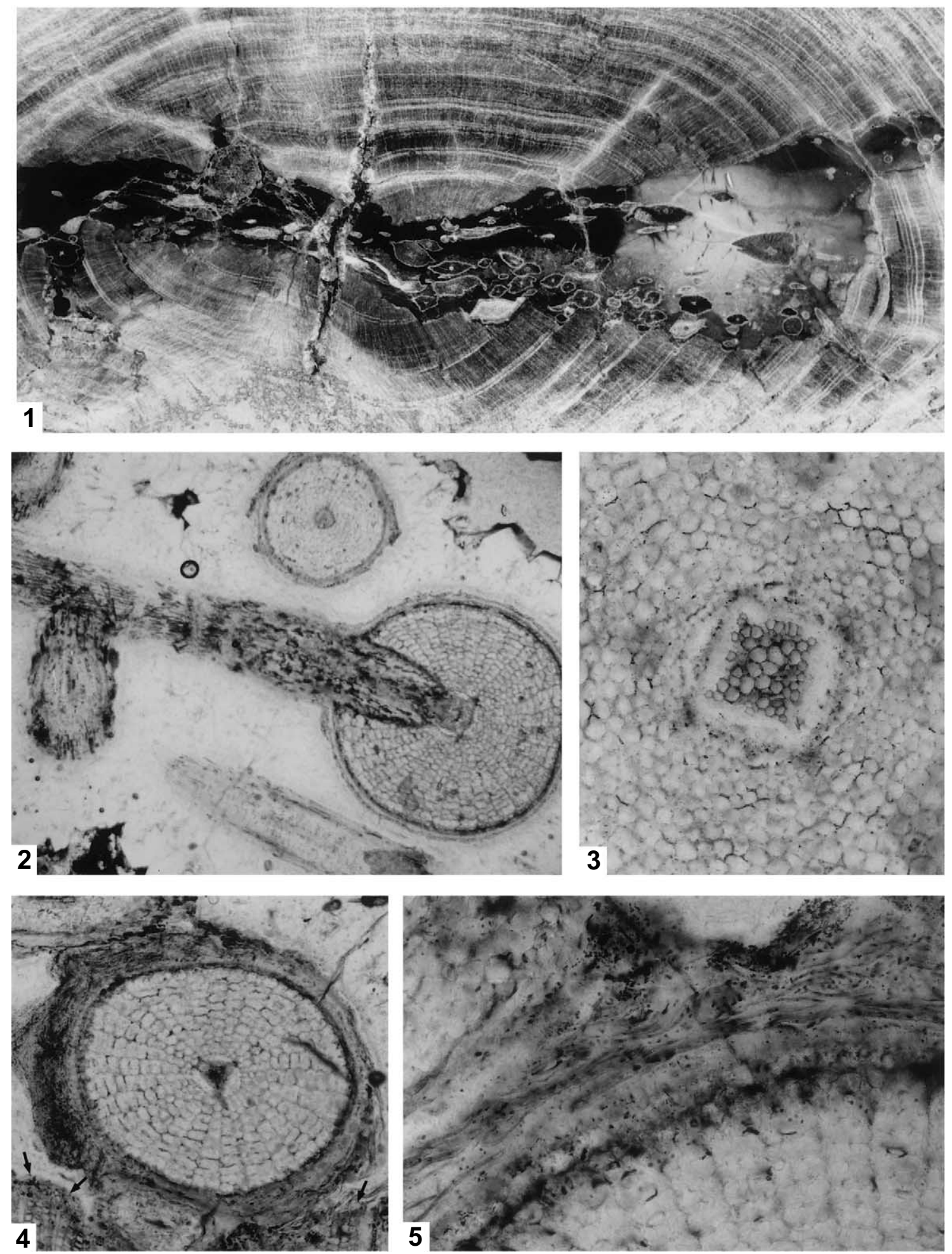
to $2-4$ cells (Plate II, 4,6); some are biseriate on one row (Plate II, 5). They occasionally contain black deposits. On tangential sections the outline of the ray cells looks more or less like a flattened ellipse, the pointed, marginal cells being higher than the median ones (Plate II, 4-6). The height of the median ray cells measures between 20 and $28 \mu \mathrm{m}$ while the marginal ones reach $32-40 \mu \mathrm{m}$. Their relatively thick (1-3.4 $\mu \mathrm{m}$ wide) horizontal walls are smooth, and appear unpitted under the light microscope. The tangential walls are most generally perpendicular (Plate IV, 6). Indentures are not present. At the point of junction of tangential with horizontal ray cell walls, a triangular widening is sometimes noticed (Plate III, 2; Plate IV, 6, arrows).

Cross-field pits vary from taxodioid to glyptostroboid. Cupressoid pits have not been observed. The pit aperture is often rounded (Plate III, 1-3; Plate IV, 2-4), although wide oval pit apertures are not rare either (Plate II, 3; Plate IV, 3,4,6). Their long axis is inclined at an angle of 0 to about $25^{\circ}$ to the horizontal wall of the ray cell. The border, if present, is always narrow. The diameter of the cross-field pits is $8-14 \mu \mathrm{m}$. Their number ranges from 1 to 6 (exceptionally 7) per cross-field. When more then two are present, the cross-field pits are usually arranged in two tiers, occasionally three tiers, and are irregularly disposed (Plate IV, 3,4,6). Numerous irregularly disposed cross-field pits are particularly obvious on the higher marginal cells but they also occur on the median ones.

Incidentally, small roots (Plate V, 1) were observed inside branch pieces, $15 / 10 \mathrm{~cm}$ wide by about $30 \mathrm{~cm}$ long, lying in-between the stumps. These have no secondary xylem; they vary from diarch and triarch (Plate V, 4) for the smallest rootlets less than $1 \mathrm{~mm}$ wide to tetrach (Plate V, 2,3) and exceptionally pentarch for the 'widest' ones $3.3 \mathrm{~mm}$ in diameter. Tiny frequently branched rootlets are seen attached to larger ones (Plate V, 2). In all sections epidermal cells lack root hairs. A mantle of hyphae surrounds each root (Plate $\mathrm{V}, 4,5$ ); tiny Hartig net hyphae occur around the cortical cells, reaching the endodermis (Plate V, 3). These small roots with ectomycorrhizal association might belong to the same taxon as the secondary wood.

\section{Identification}

The combination of distinct growth rings, smooth to sparsely pitted, horizontal and tangential walls of ray parenchyma, 1-30 cells high rays with occasionally 1-2 paired cells in the body, and 1-6 taxodioid to glyptostroboid pits in the crossfields, in association with the absence of resin ducts and spiral thickening, indicates taxodiaceous secondary xylem. In the absence of other evidence, these woods are notoriously difficult to assess because of the overlapping characters (Basinger, 1981). Furthermore, there are different opinions about the diagnostic value of these characters (Figueiral et al., 1999).

Usually, determination of taxodioid fossil secondary xylem puts special emphasis on the crossfield pits (Kräusel, 1949). However, it has been shown that the type of cross-field pitting is rather variable within a single species according to the part of the tree considered (Bailey and Faull, 1934), and only the most common type of early wood cross-field pitting should be considered (Kräusel, 1949). In addition, even in modern secondary xylem, the difference between taxodioid,

Plate V. Transversal sections through Glyptostroboxylon sp. from the Tienen Formation, Belgium, with roots in the decayed pith. Specimen ULg Réservoir 1.

1. Transverse section through a branch, general view showing sections of small roots in the decaying pith. Reflected polarised light micrograph of the polished surface. $\times 3$.

2. Detail of a branching rootlet. $\times 20$.

3. Detail of a tetrach root. Cortical cells up to the endodermis are enclosed in the Hartig net. $\times 90$.

4. A triarch root with a thick mantle of hyphae. The arrows point to the secondary xylem of the branch. $\times 35$.

5. Detail of the mantle of ectomycorrhizal hyphae. $\times 200$. 
Table 1

Comparison of the characteristics of extant Taxodioideae genera, Taxodioxylon gypsaceum, Glyptostroboxylon tenerum, and the Hoegaarden wood

\begin{tabular}{|c|c|c|c|c|c|c|c|c|c|c|c|c|c|c|c|c|c|c|c|c|}
\hline & & $\begin{array}{l}\text { Cunning- } \\
\text { hamia }\end{array}$ & $\mathrm{C}$ & Sequoia & C S & $\begin{array}{l}\text { Sequoia- } \\
\text { dendron }\end{array}$ & $\begin{array}{rl}\mathrm{C} & 1 \\
& q\end{array}$ & $\begin{array}{l}\text { Metase- } \\
\text { quoia }\end{array}$ & $\begin{array}{ll}\mathrm{C} & \mathrm{C} \\
& n\end{array}$ & $\begin{array}{l}\text { Crypto- } \\
\text { meria }\end{array}$ & $\mathrm{C}$ & Taxodium & $\begin{array}{l}\text { C Glypto- } \\
\text { strobus }\end{array}$ & $\mathrm{C}$ & $\begin{array}{l}\text { gypsa- } \\
\text { ceum }\end{array}$ & $\mathrm{C}$ & tenerum & $\mathrm{C}$ & wood & $\mathrm{C}$ \\
\hline \multirow[t]{4}{*}{ Tracheids } & $\begin{array}{l}\text { Number } \\
\text { of pits }\end{array}$ & $\begin{array}{l}1 \text { (rarely 2), } \\
(2),(3),(6)\end{array}$ & 1 & $\begin{array}{l}\text { scattered, } \\
\text { rarely } 2 \text { side } \\
\text { by side (3) }\end{array}$ & 11 & 1 (3) & $\begin{array}{ll}0 & 1\end{array}$ & 1-2(3) & 11 & 1-2-(3), (3) & 2 & $\begin{array}{l}\text { up to quadri- } 3 \\
\text { seriate (3) }\end{array}$ & $\begin{array}{l}1-2 \text {, in long } \\
\text { rows (3) up to } \\
4 \text { in thick root, } \\
\text { (10) }\end{array}$ & 1 & $\begin{array}{l}1-2-(3-4),(6), 3 \\
(8), 1-2-3(9)\end{array}$ & & $\begin{array}{ll}\text { uni- to } & 1 \\
\text { biseriate (9) }\end{array}$ & 1 & $\begin{array}{l}\text { uni- to } \\
\text { biseriate }\end{array}$ & 1 \\
\hline & $\begin{array}{l}\text { Diameter of } \\
\text { pits }\end{array}$ & 9-11 (3) & 0 & 16-18 (3) & 11 & 14-17 (3) & 12 & $20-22$ & 11 & 13-14 (3) & 0 & $\begin{array}{l}12-14(3), 8-120 \\
\text { (9) }\end{array}$ & 13-16 (3) & 1 & 14-17 (8) & 1 & $\begin{array}{l}11(10) ; 14-201 \\
\text { (9) }\end{array}$ & 1 & $14-17$ & 1 \\
\hline & Torus & present & 1 & present & $1 \mathrm{a}$ & absent (1) & $0 \mathrm{p}$ & present & $1 \mathrm{p}$ & present & 1 & present & present & 1 & present & 1 & present & 1 & present & 1 \\
\hline & $\begin{array}{l}\text { Tang. diam. } \\
\text { (early wood) }\end{array}$ & $\begin{array}{l}30-55(3), 30- \\
60(2)\end{array}$ & & $\begin{array}{l}40-50(3)-80 \\
(7), 24-60(2)\end{array}$ & 13 & 30-90 (3) & $\begin{array}{rr}1 & 6 \\
& 8\end{array}$ & $\begin{array}{l}65-85(3), 40-1 \\
85(4)\end{array}$ & 13 & 30-50 (2) & 0 & $35-90$ (2), (7) 1 & $\begin{array}{l}40-50(3), 20- \\
70(2)\end{array}$ & 1 & $\begin{array}{l}40-54-70(8), \quad 1 \\
45-48-60(9)\end{array}$ & 1 & $\begin{array}{l}40-44-50(9), \\
32-50(10)\end{array}$ & 0 & $32-40-44$ & 0 \\
\hline \multirow[t]{6}{*}{ Rays } & Height & $1-24,30$ (2) & 0 & $\begin{array}{l}1-30(2)-40+1 \\
(7)\end{array}$ & 11 & $1-20+(3)$ & $\begin{array}{ll}0 & 1\end{array}$ & $1-30(3)$ & $\begin{array}{ll}0 & 1 \\
& \\
& (\end{array}$ & $\begin{array}{l}1-30(2) ; 1-6 \\
(7),(3)\end{array}$ & 0 & up to 60 cells 1 & $1-18(-30)(3)$ & & $\begin{array}{l}1-30(8), 7-120 \\
(9)\end{array}$ & & $\begin{array}{l}1-8-14(9) \text { up } 0 \\
\text { to } 24(10)\end{array}$ & 0 & 1 up to 34 & 0 \\
\hline & Width & $\begin{array}{l}\text { partly biseriate } \\
\text { (2) }\end{array}$ & & $\begin{array}{l}\text { biseriate } \\
\text { (partly or } \\
\text { compl.) }\end{array}$ & $\begin{array}{ll}1 & \mathrm{u} \\
& \mathrm{b} \\
& \\
\mathrm{c} & \end{array}$ & $\begin{array}{l}\text { uniseriate, rare } 1 \\
\text { biseriate } \\
\text { (partly or } \\
\text { compl.) (3) }\end{array}$ & & $\begin{array}{l}\text { uniseriate, rare } 1 \\
\text { partly biseriate } \\
\text { (3) }\end{array}$ & & $\begin{array}{l}\text { partly biseriate } 1 \\
\text { (rare) }\end{array}$ & & ? & $\begin{array}{l}\text { rare } 1-2 \text { paired } \\
\text { cells (3) }\end{array}$ & & $\begin{array}{l}\text { rare paired } \\
\text { cells }(9)\end{array}$ & 1 & $\begin{array}{ll}\text { occas. paired } & 1 \\
\text { cells } & \end{array}$ & 1 & $\begin{array}{l}\text { rare } 1-3 \text { paired } \\
\text { cells }\end{array}$ & \\
\hline & Ray tracheids & present (1) & 1 & present (1), (4) 1 & & $\begin{array}{l}\text { present (4); ? } 1 \\
\text { (1) }\end{array}$ & & present (1), (4) 1 & & absent (1) & 0 & absent (1) & absent (1) & 0 & absent (8) & 0 & absent (9) & 0 & absent & 0 \\
\hline & $\begin{array}{l}\text { Hor. wall } \\
\text { pitting }\end{array}$ & thin and pitted & & $\begin{array}{l}\text { sparsly pitted } 1 \\
\text { (4) }\end{array}$ & $1 \mathrm{~s}$ & $\begin{array}{l}\text { sparsly pitted } 1 \\
\text { (4) }\end{array}$ & $\begin{array}{ll}1 \mathrm{~s} \\
& \mathrm{~s}\end{array}$ & $\begin{array}{l}\text { sparsly pitted } 1 \\
\text { (4) }\end{array}$ & & $\begin{array}{l}\text { thick and } \\
\text { smooth (3) }\end{array}$ & 0 & $\begin{array}{l}\text { thick and } \\
\text { pitted (3) }\end{array}$ & thin+warts (3) & 1 & $\begin{array}{l}\text { smooth (9) to } 1 \\
\text { pitted (6) }\end{array}$ & 1 & smooth (9) & 0 & $\begin{array}{l}\text { thin and } \\
\text { sparsly pitted }\end{array}$ & 1 \\
\hline & Indentures & $\begin{array}{l}\text { prominent in } \\
\text { early wood (2) }\end{array}$ & & $\begin{array}{ll}\text { absent (2), } & 1 \\
\text { occasional (3) }\end{array}$ & $1 \mathrm{~s}$ & shallow (3) & $\begin{array}{rl}1 & \mathrm{n} \\
& \mathrm{p}\end{array}$ & $\begin{array}{l}\text { not noted (3), } 1 \\
\text { present (7) }\end{array}$ & & prominent (2) 1 & 1 & absent (3) & $\begin{array}{l}\text { present (2); } \\
\text { none (3) }\end{array}$ & 1 & not mentioned? & $?$ & not mentioned? & $?$ & absent & 0 \\
\hline & Peculiarity & $\begin{array}{l}\text { relatively small } \\
\text { cross-field pits } \\
\text { (3) }\end{array}$ & & $\begin{array}{l}\text { resin } \\
\text { tracheids }+ \\
\text { medull. stone } \\
\text { cells (11) }\end{array}$ & & $\begin{array}{l}\text { rad.+tg. walls } \\
\text { thickn. to the } \\
\text { same extent (3) }\end{array}$ & & & & $\begin{array}{l}\text { tg. wall thin, } \\
\text { smooth (3) } \\
\text { medull. stone } \\
\text { cells (11) }\end{array}$ & & $\begin{array}{l}\text { highest rays } \\
\text { within } \\
\text { taxodiaceae (2, } \\
\text { 3) }\end{array}$ & $\begin{array}{l}\text { triang. } \\
\text { widening at } \\
\text { junction (3) }\end{array}$ & & & & & & $\begin{array}{l}\text { occasional } \\
\text { triang. } \\
\text { widening at } \\
\text { junction }\end{array}$ & \\
\hline \multirow[t]{4}{*}{ Cross-field pits } & Type & glypto-cupresso & & $\begin{array}{l}\text { taxodioid (3) } \\
\text { (5), taxo- } \\
\text { glypto- } \\
\text { (cupresso- } \\
\text { podocarpo) (4) }\end{array}$ & & $\begin{array}{l}\text { taxodioid (3) } \\
\text { (5), taxo- } \\
\text { (glypto- } \\
\text { cupresso- } \\
\text { podocarpo) (4) }\end{array}$ & & $\begin{array}{l}\text { taxodioid (3), } \\
\text { taxo-glypto- } \\
\text { (cupresso- } \\
\text { podocarpo) (4) }\end{array}$ & & $\begin{array}{l}\text { taxo to glypto } \\
\text { (2) }\end{array}$ & & taxodioid (2) & $\begin{array}{l}\text { glypto (3), } \\
\text { taxo to glypto } \\
\text { (2), (4) }\end{array}$ & & $\begin{array}{l}\text { taxo-(glypto)- } \\
\text { (cup- } \\
\text { ressoid) (6) }\end{array}$ & & $\begin{array}{l}\text { taxo to glypto } \\
\text { (9) }\end{array}$ & & taxo to glypto & \\
\hline & Number & 2-4 (2) & 0 & $\begin{array}{l}2-5(2) ; 1-6 \quad 1 \\
\text { (3) }\end{array}$ & $\begin{array}{ll}11 \\
& 1\end{array}$ & $\begin{array}{l}1-2 \text { and } 4-6 \quad 1 \\
\text { (3) }\end{array}$ & 11 & 1-2 (3) & $\begin{array}{ll}0 & 2\end{array}$ & 2-4 (2) & 0 & $\begin{array}{l}2-6 \text { (2) up } 8 \quad 1 \\
\text { (3) }\end{array}$ & $\begin{array}{l}1-8(3) ; 2-6 \\
(2),(4)\end{array}$ & 1 & $\begin{array}{l}2-6-(5),(8) ; \quad 1 \\
2-3(9)\end{array}$ & 1 & $1-4-8(9),(10) 1$ & & 1 to 7 & 1 \\
\hline & Disposition & one horizontal & & one horizontal & & $\begin{array}{l}\text { one horizontal } \\
\text { series (6) }\end{array}$ & & $\begin{array}{l}\text { side by side or } \\
\text { superposed }\end{array}$ & & one horizontal & & mostly in twos & $\begin{array}{l}2 \text { tiers, occas. } \\
3\end{array}$ & & $\begin{array}{l}\text { side by side in } \\
\text { one }\end{array}$ & & $\begin{array}{l}\text { several tiers, } \\
\text { and }\end{array}$ & & $\begin{array}{l}2 \text { tiers, occas. } \\
3\end{array}$ & \\
\hline & & $\begin{array}{l}\text { series (2); } \\
\text { superposed in } \\
\text { terminal cell } \\
\text { (3) }\end{array}$ & 0 & series (2) & $\begin{array}{ll}0 & \mathrm{o} \\
& \mathrm{a}\end{array}$ & $\begin{array}{l}\text { or two (3), } \\
\text { aperture often } \\
\text { horizontal. } \\
\text { 'elongated (6) }\end{array}$ & & (3), (7) & $1 \mathrm{~s}$ & series (2), & 1 & side by side (3) 0 & $\begin{array}{l}\text { irregularly } \\
\text { distributed (2) }\end{array}$ & 1 & $\begin{array}{l}\text { row }(8),(9), \quad 1 \\
\text { two tiers }\end{array}$ & 1 & $\begin{array}{l}\text { irregularly } \\
\text { distributed }\end{array}$ & 1 & $\begin{array}{l}\text { irregularly } \\
\text { distributed }\end{array}$ & 1 \\
\hline
\end{tabular}


half-bordered pits with wide oval aperture and narrow border, and glyptostroboid pits similar to the taxodioid ones but with a very narrow, almost invisible border (Schwarz and Weide, 1962 , p. 177), is not always easy to assess, as a variety of transitional forms occur within each species. Measurements of the length of the pit and width of the margo, followed by calculation of the Schwarz and Weide (1962) index, plus consideration of the inclination of the aperture give good clues. On the Belgian fossil secondary xylem the Schwarz and Weide index is rarely applicable, as the cross-field pits often appear corroded and with ill-defined margins when observed under the transmitted light microscope (Plate III, 1-3). Nevertheless, on the same piece of secondary xylem both types of cross-field pitting - 4-7 more or less superposed glyptostroboid pits (Plate III, 1,4; Plate IV, 3,4$)$ or $1-2$ side by side taxodioid ones (Plate III, 1,2) - are observed on early wood ray cells. Amongst the many specimens studied, both taxodioid and glyptostroboid cross-field pits are thus present, the glyptostroboid type of pitting occurring at least as frequently as the taxodioid. We have not observed typical cupressoid pits. According to Kräusel's key, the Hoegaarden secondary xylem falls between Taxodioxylon Hartig emend. Gothan and Glyptostroboxylon Conwentz. According to the last 'diagnoses' (sic) provided for Taxodioxylon and Glyptostroboxylon (Süss and Velitzelos, 1997), the difference between both genera is narrow indeed. The segregation, once again, rests on the early wood cross-field pits: they have broad apertures of more or less elongated axis (taxodioid pitting) in Taxodioxylon while they are ovoid in Glyptostroboxylon, all the other characters listed in both 'diagnoses' being identical. Süss and Velitzelos (1997) do not discuss the taxonomic value of this single feature, which is known to be rather variable even within a single extant species (Bailey and Faull, 1934). As both types of pitting occur in the Hoegaarden wood, the morphology of the cross-field pits gives no clue for its identification.

In taxodioid fossil (and extant) secondary xylem, emphasis is also put on the morphology of the horizontal wall of the secondary xylem parenchyma cells. In Glyptostroboxylon these walls are 
described as smooth, sparsely pitted (see Schönfeld, 1955 for a listing of Glyptostroboxylon specimen characters) to irregularly thickened (Gottwald, 1992). A similar range of variation is also noticed in Kräusel's descriptions of Taxodioxylon gypsaceum Göppert, the most common European Tertiary taxodiaceous secondary xylem, where the horizontal walls of the axial parenchyma are regarded as smooth to granularly thickened (Süss and Velitzelos, 1997) or as frequently nodular, the nodules being small and uneasy to observe (van der Burgh and Meijer, 1996). The validity of Glyptostroboxylon has even been questioned because $G$. tenerum (Kraus) Conwentz appears difficult to distinguish from $T$. gypsaceum (van der Burgh and Meijer, 1996, and references therein). Actually, when considering the variability of both key features, i.e. cross-field pits and wood parenchyma horizontal walls (Table 1), it is tempting indeed to synonymise $G$. tenerum and
T. gypsaceum. The formalisation of such a move, however, requires first-hand knowledge of the type-specimens plus an in-depth analysis of a variety of formerly described fragments from different localities and ages. This is beyond the scope of this paper.

Meijer (2000), while describing late Cretaceous silicified driftwood from the Aachen Formation (northeast Belgium), faced a similar problem of overlapping characteristics. Despite occurrence of so-called 'Eiporen' (sensu Kräusel, 1949) arranged in more than one horizontal row in median ray cells, he chose assignation to Taxodioxylon as Taxodioxylon cf. gypsaceum instead of Glyptostroboxylon mainly because his specimen demonstrated rootwood features, and Sequoia rootwood according to Bailey and Faull (1934) possesses similar cross-field pits. We have secondary xylem from branches and trunk bases, not from roots. These wood fragments show a variety

Table 2

Quantification of the characters

\begin{tabular}{|c|c|c|c|}
\hline \multicolumn{3}{|l|}{ Characters } & \multirow{2}{*}{$\frac{\text { Coding }}{0}$} \\
\hline Tracheids & Pit number & 1 & \\
\hline & & 2 & 1 \\
\hline & & 3 & 2 \\
\hline & & more than 3 & 3 \\
\hline & Pit diameter & less than $16 \mu \mathrm{m}$ & 0 \\
\hline & & more than $15 \mu \mathrm{m}$ & 1 \\
\hline & Torus & no & 0 \\
\hline & & yes & 1 \\
\hline & Tangential diam. & less than $61 \mu \mathrm{m}$ & 0 \\
\hline & & more than $60 \mu \mathrm{m}$ & 1 \\
\hline \multirow[t]{14}{*}{ Rays } & Height & less than 41 cells & 0 \\
\hline & & more than 40 cells & 1 \\
\hline & Width & uniseriate & 0 \\
\hline & & biseriate & 1 \\
\hline & Tracheids & no & 0 \\
\hline & & yes & 1 \\
\hline & Hor. wall & smooth & 0 \\
\hline & & pitted & 1 \\
\hline & Ìndentures & no & 0 \\
\hline & & yes & 1 \\
\hline & Cross-field pits & less than 5 & 0 \\
\hline & & more than 4 & 1 \\
\hline & Disposition & one row & 0 \\
\hline & & two rows & 1 \\
\hline \multirow{4}{*}{ Parenchyma } & Horizontal wall & smooth & 0 \\
\hline & & nodular & 1 \\
\hline & Horizontal wall & thin & 0 \\
\hline & & thick & 1 \\
\hline
\end{tabular}


of cross-field features. Their cross-field pits are nevertheless more often organised in irregularly superposed tiers rather than side by side in a line, even in median ray cells. Accordingly, we adopted a conservative position and decided for the inclusion of Hoegaarden secondary xylem in Glyptostroboxylon. In the present state of knowledge of both wood artificial taxa, our decision is comforted by the following observations: (1) the intertracheidal bordered pits are never triseriate, even on the radial walls of the widest elements, (2) the latter are smaller than those of $T$. gypsaceum (van der Burgh and Meijer, 1996, for a comparison of data from different descriptions of $T$. gypsaceum), and (3) the relatively narrow width of early wood tracheids and the height of ray cells give a peculiar appearance to the radial sections with cross-fields generally much less radially elongated than those usually illustrated for T. gypsaceum. Nevertheless, the Hoegaarden wood includes features of both Taxodioxylon and Glyptostroboxylon, illustrating the occurrence of a Tertiary taxodioid secondary xylem complex in which segregation between artificial genera is presently debatable.

Until recently Glyptostroboxylon tenerum was the only species referred to Glyptostroboxylon (for synonymy, see Kräusel, 1949; Süss and Velitzelos, 1997). Lately two more species have been added to the genus: G. microtracheidale Süss and Velitzelos 1997 and G. tendagurense Süss and Schultka 2001. Glyptostroboxylon tendagurense, known from the Upper Jurassic of East Africa, is remarkable for its extremely narrow tracheids with variable size and shape. Glyptostroboxylon microtracheidale, present in the Upper Oligocene-Lower Miocene of Lesbos (Greece), differs from the Hoegaarden secondary xylem in the arrangement of its radially shortened tracheids which are disposed in irregular rows.

Glyptostroboxylon tenerum is considered as widespread in the European Cenozoic (van der Burgh, 1973, and references therein; Mai, 1995), but no recent detailed description is available. Stockmans and Willière (1934) recorded G. tenerum at Leval-Trahegnies in Belgium, a locality of about the same age as Hoegaarden, but the description is very short and the drawings uninfor- mative. The specimens attributed to $G$. tenerum from brown coal of the Lower Rhine Embayment by van der Burgh (1973) appear to be different from those of Hoegaarden. They are instead regarded as belonging to Taxodioxylon by Süss and Velitzelos (1997), a divergence of opinion illustrating once more the difficulty in distinguishing between Taxodioxylon and Glyptostroboxylon. Our specimens are more comparable to $G$. tenerum Eocene silicified material from brown coal pits near Leipzig (Germany), but on transverse sections the German secondary xylem shows a looser arrangement of the tracheids with open, recognisable intercellular spaces (Schönfeld, 1955, Taf. 7, Abb. 54). The G. tenerum phosphatised driftwood described by Gottwald (1992) from the Late Eocene of Helmstedt (Germany) is similar to the Belgian Glyptostroboxylon, but cross-fields with single pits are apparently not present. We therefore decided not to refer the Hoegaarden secondary xylem to G. tenerum. It is designated as Glyptostroboxylon sp. to emphasise its unique combination of characteristics pointing to the Glyptostroboxylon type of fossil wood genus, but with several traits, notably the horizontal wall pitting of the wood parenchyma cells, of Taxodioxylon gypsaceum.

\section{Discussion and comparison with modern taxodiaceous taxa}

Recently, several clades have been identified within taxodiaceous taxa leading to a more informative infrafamilial classification (Gadek et al., 2000; Kusumi et al., 2000), Sciadopitys Siebold et Zucc. being transferred to the monotypic family of the Sciadopityaceae Luerss. (Farjon, 1998).

The Taiwanioideae (Hayata) Quinn and Athrotaxidoideae Quinn have secondary xylem different from the Hoegaarden specimens, showing smaller bordered pits on their tracheids, shorter rays (rarely exceeding 10 cells high in Athrotaxis D. Don), and smaller cross-field pits which are distinctly cupressoid in Taiwania Hayata (Peirce, 1936; Greguss, 1955).

The gross morphology of the secondary xylem of monogeneric Cunninghamioideae (Siebold et 
Zucc.) Quinn is close to the Belgian specimens, especially in the size of the cells and the outline of the cross-fields. Actually, according to Gothan (1905), Glyptostroboxylon is comparable to the wood of both the extant genera Cunninghamia R. Brown and Glyptostrobus Endl. Cunninghamia rays with pointed marginal cells, higher than the median ones, as seen on tangential sections, have the same appearance indeed as those of the Hoegaarden wood. However, the tracheids usually show only uniseriate bordered pits on the radial walls, and thus constitute an exception to the usual occurrence of biseriate-bordered pits, a feature shared by all other taxodiaceous secondary xylem (van der Burgh and Meijer, 1996; Table 1). Moreover, Cunninghamia possesses ray tracheids (Gadek et al., 2000), but these are obviously difficult to observe as they are not mentioned in earlier literature, and non-observation of ray tracheids on fossil taxodiaceous wood may not preclude their occurrence (Basinger, 1981). In Cunninghamia, 2-4 glyptostroboid to cupressoid pits, and apparently no taxodioid ones, are arranged in one horizontal series in the cross-fields but superposed pits are also noticed, particularly in the terminal cells of the rays (Table 1). These differences between Cunninghamia and Glyptostroboxylon sp. wood anatomy are difficult to evaluate, more so as divergence of opinion still exists particularly about the morphology of the radial walls of the secondary xylem parenchyma cells (see Table 1). Anyway, both present-day species, C. konishii and $C$. lanceolata, which are very similar and should perhaps be treated as varieties of a single species (Farjon, 1998), are often multitrunked, an observation never made at Hoegaarden where only stumps standing singly are recorded.

If a consensus exists on the members - Sequoia Endlicher, Metasequoia $\mathrm{Hu}$ et Cheng and Sequoiadendron giganteum Buchholz - of the Sequoideae clade, on those of the Taxodioideae there is debate. According to Gadek et al. (2000), the Taxodioideae clade includes Taxodium L.C. Richard, Cryptomeria D. Don and Glyptostrobus, while Kusumi et al. (2000) conclude that Taxodium and Glyptostrobus form a clade which is in a sister-group relationship to Cryptomeria.
Cryptomeria, with up to 3-seriate bordered pits on the radial walls of its tracheids, strongly nodular parenchyma horizontal walls, thickened horizontal walls of the ray cells with well discernible indentures, is clearly different from the Hoegaarden wood (Table 1).

The Sequoideae have heterocellular rays, although these are not common. They are considered to have smooth horizontal walls in the xylem parenchyma, as opposed to the dentate ones of the Taxodioideae (e.g. Greguss, 1955). However, disagreement is obvious on this key distinguishing feature (Table 1). We are not in a position to decide between these conflicting observations. Other characters are helpful. Sequoiadendron is the only taxodiaceous secondary xylem without a torus on the membrane of intertracheidal pit pairs. A torus is present on the Belgian wood (Plate II, 4; Plate III, 4). The size of the Sequoideae tracheids is also different. Tracheid size depends on growth rate and the vertical and lateral position on the tree of the studied branch or trunk material, and is thus of questionable taxonomic importance. Nevertheless, the maximum tangential diameter of the tracheids in the outermost part of a stem gives a rough indication about stem height (Stockey et al., 2001, and references therein). The tallest known living trees possess early wood tracheids with the widest tangential diameter (up to 85 and $90 \mu \mathrm{m}$ for Sequoia and Sequoiadendron; Table 1). In Glyptostroboxylon sp. from Hoegaarden the widest measured tangential diameter reaches $44 \mu \mathrm{m}$ only. Even if it cannot be ascertained that this dimension represents the widest tracheids, as we know neither the age nor the stage of maturity reached by the stumps, Glyptostroboxylon from Hoegaarden nevertheless appears to belong to smaller trees than the giant Sequoideae.

Within the Taxodioideae, Taxodium distichum (L.) Rich has strongly nodular horizontal walls of secondary xylem parenchyma cells. It also possesses the tallest rays (up to 60 cells high) and its tracheids are much wider than in Glyptostroboxylon sp., with up to 4-seriate bordered pits on the radial walls (Table 1). Similarity with secondary xylem of Glyptostrobus pensilis (Staunton ex D. Don) K. Koch is greater. Indentures have been 
reported as regularly present (Peirce, 1936), at least in the early wood (Schönfeld, 1955). However, according to Greguss (1955), at the point of junction with horizontal walls, the tangential ray cell walls widen in the shape of a triangle. A similar triangular enlargement is occasionally noticed on the Belgian Glyptostroboxylon sp. Glyptostrobus pensilis shows pitting on the horizontal walls of ray parenchyma cells, a character which is more dubious on Glyptostroboxylon sp. Owing to the relative tangential diameter and height of the ray cells, early wood cross-fields are similar in outline in both fossil and extant woods. Bordered pits on the radial walls of early wood tracheids are of similar diameter to the lower range of taxodiaceous secondary xylem pit dimension (Table 1). The transverse walls of the vertical wood parenchyma cells of $G$. pensilis are, once more, variously described as simply pitted or with inconspicuous thickenings or as distinctively nodular but with small nodules (Table 1). Anyway, the difference between Glyptostroboxylon sp. from Hoegaarden and extant G. pensilis wood is narrow, the most obvious difference being the usually higher number of pits/cross-field and their narrower diameter in the modern species. The importance of these discrepancies in relation to preservation bias, nature of environmental signature, physiology and development of the source trees is presently impossible to assess.

The affinities of the Hoegaarden wood to some taxa with roughly comparable secondary xylem (Table 1) were also estimated through a cladistic analysis. The analysis was based on 10 taxa and 13 characters, listed in Table 1 . Some characters have been arbitrarily coded such as the tracheid tangential diameter, coded 0 for diameters under $60 \mu \mathrm{m}$ and 1 for larger diameters (see coding for each character, columns marked $\mathrm{C}$ in Tables 1 and 2). The Branch-and-Bound routine of PAUP (version 3.1.1; Swofford, 1991) generated one single tree of 21 steps, with consistency index of 0.667. This phenogram (Fig. 5) confirms our more intuitive analysis, as the Hoegaarden wood appears to share the closest similarities with Glyptostroboxylon, and to a lesser extent with Taxodium and Taxodioxylon. Furthermore, the analysis places Glyptostrobus in a sister-group relationship with a complex comprising Taxodium, Taxodioxylon, Glyptostroboxylon, and the Hoegaarden wood.

In summary, the secondary wood from Hoegaarden is similar in gross morphology to extant Cunninghamia but clearly distinct from the modern genus when considering anatomical details. Several features (more particularly the variability in the cross-field pit type) are shared with extant Sequoia wood, but Belgian Glyptostroboxylon sp. appears most similar, although not identical, to living Glyptostrobus secondary wood.

The taxodiaceous conifers have a very long fossil history, originating during the Triassic (Yao et al., 1997) and being well established by Jurassic time (Basinger, 1981; Stewart and Rothwell, 1993). Evidence for Cunninghamia-type fossils occurs as early as the Middle Jurassic with several genera of permineralised seed cones, some wood pieces and compressed vegetative and fertile remains (Yao et al., 1998, and references therein). The earliest fossil identified as Cunninghamia dates back to the Hauterivian-Barremian (middle Early Cretaceous) of Inner Mongolia (Kester, 2000) but fossil cones most similar to those of Cunninghamia are known to occur in the Lower Cretaceous beds of California (Miller, 1974). On the basis of parsimony analysis of nucleotide sequence data from the plastid genes matK and $r b c L$, together with non-molecular data considerations (Gadek et al., 2000) as well as of nucleotide sequences from three additional chloroplasts genes (Kusumi et al., 2000), Cunninghamia was the first indeed to separate within the taxodiaceous lineage. The order of divergence of both sequoioid and taxodioid clades, although resolved, receives less support, but apparently they both diverged after separation of Cunninghamia, Taiwania and Athrotaxis (Gadek et al., 2000; Kusumi et al., 2000). A glyptostroboid type of wood is already recognised by the Upper Jurassic in East Africa (Süss and Schultka, 2001). Taxodioxylon gypsaceum is present in the Cretaceous (Meijer, 2000). Occurrence of secondary xylem, the overlapping characteristics of which appear to be shared by both Taxodioxylon and Glyptostroboxylon in the very early Eocene once more points to the structural unity of this 
taxodioid type of wood, while seeds belonging to three modern genera, Glyptostrobus, Sequoia and Taxodium, are already recognised in Middle European Cenomanian strata (Knobloch and Mai, 1986).

\section{Taphonomic considerations}

Examples of stumps transported in upright position in mudflows (e.g. in those generated by the Mount Saint Helen's eruption; Karowe and Jefferson, 1987) are well known. As is the case for the Hoegaarden stumps, they are less than $2 \mathrm{~m}$ high and possess a wide base with no or very few roots remaining. A matrix different from the surrounding sediment is often noticed in their rootballs, a character by which they differ from the Hoegaarden stumps (Chapman, 1994, and references therein). At Hoegaarden the stumps are 1-3 $\mathrm{m}$ apart, and, as already noticed in the nearby Overlaar area, distributed in a similar way as in some modern virgin conifer forests. Clearly, the density of the stumps is a good argument for their in situ position. The large geographical extent of the lignitic layer on which the stumps are to be found precludes the hypothesis of small rafts of forest floor with standing trees having been transported several times (Karowe and Jefferson, 1987). In addition, occurrence of roots reaching the underlying sandstone reinforces the argument. No roots are preserved between the stump bases and the massive sandstone in which undeterminable root casts only rarely are observed. The alteration of wood is greatly influenced by the embedding sediment and its permeability (Weibel, 1996), and all the original organic content including roots have been leached out of the permeable white sands, a process most probably resulting from variations in the water table level and in its physical and chemical characteristics. As a consequence also of considerable variations in the water table levels, accumulated dead organic material in the peat decayed while the stumps, sitting on poorly permeable lignitic clay, were permineralised by silica-rich water percolating through the overlying sandy deposits, silica precipitation during petrifaction being templated by the organic molecules of the dead wood tissues (Martin, 1999).

\section{Palaeoenvironmental considerations}

At Hoegaarden the bases of the stumps are embedded in a lignite layer (unit 5; Figs. 2 and 3). The Hoegaarden trees were lignite builders consistently colonising lowland habitats and living in a swampy but nevertheless irregularly water stressed environment. Water stresses, consequence either of low or high water levels, caused the development of false growth rings in addition to regular, seasonally induced ones.

Present-day Taxodioideae are often found in swampy environments, particularly both deciduous swamp cypresses, Glyptostrobus pensilis and Taxodium distichium. These peat builders share similar ecological requirements. One of the remaining populations of the globally threatened G. pensilis, with more than 200 individuals, is to be found in a swampy area, in the Da Lak province at about $500 \mathrm{~m}$ altitude in the central highlands of Vietnam (Source book of Existing and Proposed Protected Areas in Vietnam, 2001). Glyptostrobus pensilis is scattered also in southern China and occurs to as far as $13^{\circ} \mathrm{N}$ in Vietnam, attesting to its wide amplitude of ecological tolerance (Li, 1953). It thrives in damp places usually at low elevation, on river banks and next to inundated rice fields. In the eastern US Taxodium distichum is widespread in swamps and on waterlogged lakeshores where it usually occurs in pure stands but with sparse understory angiosperm trees on drier sites. Such a Taxodium consociation could provide a likely modern analogue for the Hoegaarden fossil forest in which the spacing of the taxodiaceous stumps is similar as in some modern intact swamp forests.

On the other hand, extant Sequoia sempervirens (D. Don) Endl is often assumed to be the nearest living relative to Taxodioxylon gypsaceum (van der Burgh and Meijer, 1996, and references therein), which also shares characteristics with the Hoegaarden Glyptostroboxylon sp. Such an assumption is questionable, independent from the difficulties raised by the variability of this taxodia- 
ceous wood. The coast redwoods which include the tallest known trees are now restricted to the foggy coastal belt of northern California. They are not peat builders, as opposed to Taxodioxylon gypsaceum which is commonly found in European Tertiary lignite. A hypothetical change in ecological requirements of $S$. sempervirens (Jurasky, 1936, in Mai, 1995) through time does not provide an answer to the disagreement. Obviously within the fossil taxodioid complex of secondary wood, anatomical information is on itself insufficient for deduction of precise taxonomic affinities with a modern species. This is particularly true for the Hoegaarden wood.

\section{Other macrofossil remains from the Tienen Formation}

Nearby coeval fossil localities may provide helpful additional macrofossil remains to reconstruct the plant landscape, as more than 30 fossil localities are known from the Tienen Formation in strata encompassing the Palaeocene/Eocene transition in Belgium. Yet, most of them, with the exception of Dormaal, Trieu de Leval and Hoegaarden, are known only from small outcrops or boreholes. The Dormaal Sand Member is famous for the richness and diversity of the vertebrate assemblage it yields. It is located at the base of the Tienen Formation (Steurbaut et al., 1999), and is slightly older than the Hoegaarden lignitic bed. Silicified wood of Populoxylon Mädel-Angeliewa (Doutrelepont et al., 1997) plus angiosperm fruits and seeds are present at Dormaal, but no gymnosperm remains are recorded. The Dormaal plant assemblage is characterised by the abundance of fleshy fruits, drupes and berries produced by climbing plants, especially woody lianas (Fairon-Demaret and Smith, 2002) that are known to play an important role in forest types in a warm moist climate (Morley, 2000). According to palynological analyses of the Dormaal Sands, the assemblage that also yields a variety of fern spores is dominated by Juglandaceae, and includes Myricaceae, Restionaceae, Pinaceae, and two taxa of Normapolles (Steurbaut et al., 1999). The correlative Trieu de Leval locality in the Mons Basin yields a diversified leaf assemblage with a paratropical signature according to Marty (1907). In addition, numerous charred secondary xylem remains have been recently collected. Apart from angiosperm secondary xylem remains, several pieces of Glyptostroboxylon $\mathrm{sp}$. identical to the Hoegaarden taxon have been identified. The embedding sediment yields a diverse palynoflora (Petricevic, 2000) with, amongst other taxa, many Inarperturopollenites hiatus (Potonié) Thompson et Pflug, the mother plant of which is Taxodium or/and Glyptostrobus. Huppaye, located along the Namur-Tienen railway track about $16 \mathrm{~km}$ from Tienen, is another fossil locality in the Tienen Formation. Its position within the Formation is not well constrained, but its age appears similar to Hoegaarden. The plant remains of Huppaye studied by Gilkinet (1925) are preserved in a very hard whitish micrite. The assemblage is diverse, yielding a variety of fern pinnules with a majority of Lygodium remains, several types of eudicot and palm leaves, well preserved internal and external moulds of Ericaceae capsules and many gymnosperm remains. Taxodiaceous twig fragments and cones called 'Athrotaxis (Sequoia) couttsiae' by Gilkinet (1925) are especially numerous; they occur as 3-D empty casts without any organic matter preserved. This association of remains trapped in the sandy sediment illustrates a rich and diverse flora with a wet, warm signature.

Palynological remains, gymnosperm leaf litter and roots have been destroyed at Hoegaarden by oxidative taphonomic processes and diagenesis. It can be argued that the same might explain the absence of angiosperm remains. Of course gymnospermous secondary xylem is more resistant to decay than angiospermous wood (Lücke et al., 1999; Figueiral and Mosbrugger, 2000). Lignin of the latter is typically degraded into water-soluble products and hence is rapidly destroyed, whereas the gymnosperm lignin decays into water-insoluble products (Hatcher and Clifford, 1997; Kim and Singh, 2000). However, we think that the non-occurrence of angiosperm remains at Hoegaarden is not to be attributed to taphonomic bias. The monospecific character of the Hoegaarden in situ forest is linked to the spec- 
ificity of its swampy coastal alluvial floodplain environment as deduced by sedimentological data.

In another Glyptostroboxylon sp. locality described in younger, Upper Eocene, sediments on the Isle of Wight no other plant macrofossils occur with the lignitified and occasionally heavily pyritised stumps. They also are thought to have grown as monospecific stands in a waterlogged habitat, occupying swampy areas within the vegetation of a coastal alluvial floodplain (Fowler et al., 1973).

\section{Conclusions}

The fossil forest deposit of Goudberg-Overlaar, at Hoegaarden, has been known since the middle of the nineteenth century. For the first time an anatomical analysis of the silicified stumps and trunk fragments allows their attribution to a single taxon. The anatomical structure of the secondary wood specimens shows characteristics shared by Taxodioxylon gypsaceum and Glyptostroboxylon tenerum, but affinities with the latter are closer. We chose the conservative attribution Glyptostroboxylon sp.

The long lasting controversy about the autochthonous or allochthonous origin of the stumps is resolved, favouring the in situ character of the fossil forest. Such a conclusion is based on the upright position of the great majority of the stumps, their distribution in the field, and the embedding of the stump bases within a single lignitic layer, implying a continuum in the fossiliferous deposit. Thus, the fossil deposit corresponds to remains of a natural forest rather than to a rafted secondary accumulation of stumps.

This apparently monospecific population of taxodiaceous gymnosperms is suggestive of a swamp with oscillating water table levels not dissimilar in appearance to a present-day Bald Cypress dominated swamp. Such an understanding of the palaeoenvironment of the Hoegaarden fossil forest is in agreement with sedimentological and stratigraphical data demonstrating that the trees grew in fluctuating fluvio-lacustrine settings. The Hoegaarden taxodiaceous swamp forest most probably developed during the IETM (formerly
LPTM) at about $55 \mathrm{Ma}$, when climate was the warmest of the entire Cenozoic.

\section{Acknowledgements}

All the team members are very grateful to Dr. Piet Laga of the Belgium Geological Survey for his generous sharing of information and to Hugo De Potter of the IRSNB for his active help in the field. We also thank Mr. M. Dejean, secrétaire du Cercle géologique du Hainaut, for his generous loan of several specimens to Professor C. Dupuis, and Professor N. Vandenberghe for providing the original picture of the Goudberg Section. Special thanks are due to Mr. J. Kerkhof and Mr. H. Mestdagh (Vlaamse Landmaatschappij) and Mr. C. Van Duffel (TUC rail society) for logistic help in the field. We also thank Dr. Catherine PrivéGill for her advice in determining the fossil secondary xylem, Dr. Philippe Steemans for his help in preparing the manuscript, Mr. Stefaan Van Simaeys for additional information on the palynomorph content of some samples, and Mrs. Marcella Giraldo-Martin and Mr. Fernand Noebert for their technical support during the preparation of the palynological samples and thin sections. Dr. Chris Berry kindly accepted to correct the English text. We would like to thank also Dr. J.F. Basinger and Dr. I. Figueiral for their helpful reviews of the manuscript. This work has benefited from financial support by Grant FRFC-IC 2.4540.99 of the Belgian National Fund of Scientific Research. P. Gerrienne is an FNRS Research Associate.

\section{References}

Bailey, I.W., Faull, A.F., 1934. Structural variability in the Redwood, Sequoia sempervirens, and its significance in the identification of fossil woods. J. Arnold Arbor. 15, 233254

Bains, S., Corfield, R.M., Norris, R.D., 1999. Mechanisms of climate warming at the end of the Paleocene. Science 285 724-727.

Basinger, J.F., 1981. The vegetative body of Metasequoia milleri from the Middle Eocene of southern British Columbia. Can. J. Bot. 59, 2379-2410. 
Berggren, W.A., Kent, D.V., Swisher, C.C. III, Aubry, M.-P., 1995. A revised Cenozoic geochronology and chronostratigraphy. In: Berggren, W.A., et al. (Eds.), Geochronology, Time Scales and Global Stratigraphic Correlation. SEPM Special Publications 54, pp. 129-212.

Besse, J., Courtillot, V., 1991. Revised and synthetic apparent polar wander paths of the African, Eurasian, North American and Indian plates, and true polar wander since $200 \mathrm{Ma}$. J. Geophys. Res. 96, 4029-4050.

Bone, D.A., 1986. The stratigraphy of the Reading Beds (Palaeocene), at Felpham, West Sussex. Tert. Res. 8, 17-32.

Bowen, G.J., Koch, P.L., Gingerich, P.D., Norris, R.D., Bains, S., Corfield, R.M., 2001. Refined isotope stratigraphy across the continental Paleocene-Eocene boundary on Polecat Bench in the Northern Bighorn Basin. In: Gingerich, P.D. (Ed.), Paleocene-Eocene Stratigraphy and Biotic Change in the Bighorn and Clarks Fork Basins, Wyoming. Papers on Paleontology 33, pp. 73-88.

Chapman, J.L., 1994. Distinguishing internal developmental characteristics from external palaeoenvironmental effects in fossil wood. Rev. Palaeobot. Palynol. 81, 19-32.

Doutrelepont, H., Smith, T., Damblon, F., Smith, R., Beeckman, H., 1997. Un bois silicifié de peuplier de la transition Paléocène-Eocène de Dormaal, Belgique. Bull. Inst. r. Sci. nat. Belg. Sci. Terre 67, 183-188.

Dupuis, C., Steurbaut, E., De Coninck, J., Riveline, J., 1998. The Western Argiles à lignite facies. Cap-d'Ailly sections. In: Thiry, M., Dupuis, C. (Eds.), The Palaeocene/Eocene boundary in Paris Basin: The Sparnacian deposits. Field Trip Guide, Ecole des Mines de Paris, Mém. Sci. Terre 34 (9), pp. 60-71.

Ellison, R.A., Knox, R.W.O'B., Jolley, D.W., King, C., 1994. A revision of the lithostratigraphical classification of the early Palaeogene strata of the London Basin and East Anglia. Proc. Geol. Assoc. 105, 187-197.

Fairon-Demaret, M., Smith, T., 2002. Fruits and seeds from the Tienen Formation at Dormaal, Paleocene-Eocene transition in eastern Belgium. Rev. Palaeobot. Palynol. 122, 4762.

Farjon, A., 1998. World checklist and bibliography of Conifers. The Royal Botanical Gardens, Kew.

Figueiral, I., Mosbrugger, V., 2000. A review of charcoal analysis as a tool for assessing Quaternary and Tertiary environments: Achievements and limits. Palaeogeogr. Palaeoclimatol. Palaeoecol. 164, 397-407.

Figueiral, I., Mosbrugger, V., Rowe, N.P., Ashraf, A.R., Utesher, T., Jones, T.P., 1999. The Miocene peat-forming vegetation of northwestern Germany: An analysis of wood remains and comparision with previous palynological interpretations. Rev. Paleobot. Palynol. 104, 239-266.

Fowler, K., Edwards, N., Brett, D.W., 1973. In situ coniferous (Taxodiaceous) tree remains in the Upper Eocene of southern England. Palaeontology 16, 205-217.

Gadek, P.A., Alpers, D.L., Heslewood, M.A., Quinn, C.J., 2000. Relationships within Cupressaceae sensu lato: A combined morphological and molecular approach. Am. J. Bot. 87, 1044-1057.
Gilkinet, A., 1925. Flore fossile du Landénien de Huppaye Mém. Soc. géol. Belg., vol. 4, pp. 5-28.

Godinot, M., 2000. Primate diversity during the Eocene in Europe and North America and its climatic implications. In: Schmitz, B., et al. (Eds.), Early Paleogene Warm Climates and Biosphere Dynamics. GFF 122, pp. 60-61.

Gothan, W., 1905. Zur Anatomie lebender und fossiler Gymnospermen-Hölzer. Abh. preuss. geol. Landesanst. 44, 1108.

Gottwald, H., 1992. Hölzer aus marinen Sanden des oberen Eozän von Helmstedt (Niedersachsen). Palaeontographica B 225, 27-103.

Greguss, P., 1955. Identification of living Gymnosperms on the basis of xylotomy. Akadémiai Kiadó, Budapest.

Gulinck, M., 1948. Sur des phénomènes de glissement sousaquatique et quelques structures particulières dans les sables landéniens. Bull. Soc. belg. Géol. Paléontol. Hydrol. 57 (1), $12-30$.

Hatcher, P.G., Clifford, D.G., 1997. The organic geochemistry of coal: From plant material to coal. Organ. Geochem. 5/6, 251-274.

Hauregard, F., 1999. La Transition Paléocène-Eocène dans la région de Tirlemont (Tienen): Contribution à la reconstitution des paléonenvironnements continentaux. M.Sc. Thesis, Université de Liège, $59 \mathrm{pp}$.

Henry, A., McIntyre, M., 1926. The swamp cypresses, Glyptostrobus of China and Taxodium of America, with notes on allied genera. Proc. R. Irish Acad. 37, B, 90-124.

Huard, J., 1966. Etude anatomique des bois de conifères des couches à lignite néogènes des Landes. Mém. Soc. géol. Fr. (nouv. sér.) 105, 85 pp.

Karowe, A.L., Jefferson, T.H., 1987. Burial of trees by eruption of Mount St. Helens, Washington: Implications for the interpretation of fossil forests. Geol. Mag. 124, 191-204.

Kester, P.R., 2000. Tracking the radiation and regional extinctions of the genus Cunninghamia (Taxodiaceae) (abstract). Am. J. Bot. 87, 81.

Kim, Y.S., Singh, A.P., 2000. Micromorphological characteristics of wood biodegradation in wet environments: A review. IAWA J. 21, 135-155.

Knobloch, E., Mai, D.H., 1986. Monographie der Fruchte und Samen in der Kreide von Mitteleuropa. Rozpr. Ustred. Ust. Geol. Praha 47, 1-219.

Koch, P.L., Zachos, J.C., Gingerich, P.D., 1992. Correlation between isotope records in marine and continental carbon reservoirs near the Palaeocene/Eocene boubdary. Nature 358, 319-322.

Kräusel, R., 1949. Die fossile Koniferenhölzer, II Teil. Kritische Untersuchungen zur diagnostik lebender und fossiler Koniferenhölzer. Palaeontographica B 89, 83-203.

Kuczumov, A., Vekemans, B., Schalm, O., Dorriné, W., Chevallier, P., Dillmann, P., Ro, C.-U., Janssens, K., Van Grieken, R., 1999. Analyses of petrified wood by electron, $\mathrm{X}$-ray and optical microprobes. J. Anal. At. Spectrom. 14, 435-446.

Kusumi, J., Tsumura, Y., Yoshimaru, H., Tachida, H., 2000. Phylogenetic relationships in Taxodiaceae and Cupressaceae 
sensu stricto based on $m a t K$ gene, chlL gene, $t m L-t m F$ IGS region, and $t m L$ intron sequences. Am. J. Bot. 87, 14801488.

Ledoux, A., 1910. Sur une forêt fossile du Landénien supérieur à Overlaer lez-Tirlemont. Ann. Soc. géol. Belg. 37, M39M45.

Li, H.-L., 1953. Present distribution and habitats of the Conifers and Taxads. Evolution, pp. 245-261.

Lücke, A., Helle, G., Schleser, G.H., Figueiral, I., Mosbrugger, V., Jones, T.P., Rowe, N.P., 1999. Environmental history of the German Lower Rhine Embayment during the Middle Miocene as reflected by carbon isotopes in brown coal. Palaeogeogr. Palaeoclimatol. Palaeoecol. 154, 339-352.

Luterbacher, H.P., Hardenbol, J., Schmitz, B., 2000. Decision of the voting members of the International Subcommission on Paleogene Stratigraphy on the criterion for the recognition of the Paleocene/Eocene boundary. Newslett. Int. Subcomm. Paleogene Stratigr. 9, p. 13.

Lyell, C., 1852. On the Tertiary strata of Belgium and French Flanders, Part II. The Lower Tertiary of Belgium. Quart. J. Geol. Soc. Lond. 8, 277-370.

Magioncalda, R., Dupuis, C., Blamart, D., Fairon-Demaret, M., Perreau, M., Renard, M., Riveline, J., Roche, M., Keppens, E., 2001a. L'excursion isotopique du carbone organique $\left({ }^{13} \mathrm{Corg}\right)$ dans les paléoenvironnements continentaux de l'intervalle Paléocène/Eocène de Varengeville (Haute Normandie). Bull. Soc. géol. Fr. 172, 349-358.

Magioncalda, R., Dupuis, C., Steurbaut, E., Van Simaeys, S., De Coninck, J. 2001b. The Palaeocene/Eocene C.I.E. in continental organic carbon in the Paris Basin (Haute-Normandie). Climate and Biota of the Early Paleogene. Abstracts International Meeting, July 3-8, 2001, Northwest College, Powell, WY, p. 61.

Mai, D., 1995. Tertiäre Vegetationsgeschichte Europas. Gustav Fisher, Jena.

Martin, R.E., 1999. Taphonomy - A Process Approach. Cambridge Paleobiology Series 4, Cambridge University Press, Cambridge.

Marty, P., 1907. Etudes sur les végétaux fossiles du Trieu de Leval (Hainaut). Mém. Mus. r. Hist. nat. Belg. 5, 1-52.

Meijer, J.J.F., 2000. Fossil woods from the Late Cretaceous Aachen Formation. Rev. Palaeobot. Palynol. 112, 297-336.

Miller, C.N., 1974. Petrified cones and needle-bearing twigs of a new taxodiaceous conifer from the Early Cretaceous of California. Am. J. Bot. 62, 706-713.

Moorkens, T., Steurbaut, E., Jutson, D., Dupuis, C., 2000. The Knokke borehole of northwestern Belgium re-analysed: New data on the Paleocene/Eocene transitional strata in the southern North Sea Basin. In: Schmitz, B., et al. (Eds.), Early Paleogene Warm Climates and Biosphere Dynamics. GFF 122, pp. 111-114.

Morley, R.J., 2000. Origin and Evolution of Tropical Rain Forests. Wiley, Chichester, $362 \mathrm{pp}$.

Norris, R.D., Röhl, U., 1999. Carbon cycling and chronology of climate warming during the Palaeocene/Eocene transition. Nature 401, 775-778.

Norris, R.D., Röhl, U., 2000. Astronomically-tuned chronol- ogy for the Palaeocene/Eocene transition. In: Schmitz, B., et al. (Eds.), Early Paleogene Warm Climates and Biosphere Dynamics. GFF 122, pp. 117-118.

Ostojski, D., 2001. Etude palynologique de la transition Paléocène-Eocène dans les dépôts continentaux de Morialmé et de Lincent: Contribution à la reconstitution des milieux continentaux et comparaison avec les dépôts lagunaires et laguno-marins du sondage de Kallo. M.Sc. Thesis, Université de Liège, 43 pp.

Peirce, A.S., 1936. Anatomical interrelationships of the Taxodiaceae. Trop. Woods 46, 1-15.

Petricevic, D., 2000. Etude des micro- et macrofossiles végétaux de la Transition Paléocène-Eocène (Tertiaire) de Leval (Bassin de Mons, Belgique). M.Sc. Thesis, Université de Liège, $53 \mathrm{pp}$.

Rutot, A., 1887. Course géologique du 28 août 1887 d'Esemael à Tirlemont par Grossoncourt, Autgaerden et Hoegaerden. Bull. Soc. belg. Géol. 1 (Procès-verbal), pp. 171-177.

Schönfeld, G., 1955. Die Kieselhölzer aus der Braunkohle von Böhlen bei Leipzig. Palaeontographica B 99, 1-83.

Schwarz, O., Weide, E., 1962. Systematische Revision der Gattung Sequoia Endl. Feddes Repert. 66, 159-192.

Sintubin, M., Laga, P., Vandenberghe, N., Kenis, I., Dusar, M., 2000. Deformation features in Paleogene sands in the Hoegaarden area (Belgium). Geol. Belg. 3, 257-269.

Smith, T., 2000. Mammals from the Paleocene-Eocene transition in Belgium (Tienen Formation, MP7): Palaeobiogeographical and biostratigraphical implications. GFF 122, 148-149.

Smith, T., Smith, R., 1996. Synthèse des données actuelles sur les vertébrés de la transition Paléocène-Eocène de Dormaal (Belgique). Bull. Soc. belg. Géol. 104, 119-131.

Smith, R., Smith, T., Steurbaut, E., 1999. Les élasmobranches de la transition Paléocène-Eocène de Dormaal (Belgique): Implications biostratigraphiques et paléogéographiques. Bull. Soc. géol. Fr. 170, 327-334.

Source book of Existing and Proposed Protected Areas in Vietnam, 2001.http://www.wing-wbsj.or.jp/ vietnam/source _book/index.htm.

Stainier, X., 1909. Un gisement de troncs d'arbres debouts dans le Landénien supérieur. Bull. Soc. belg. Géol. 23, 270-280.

Steurbaut, E., 1998. High resolution holostratigraphy of Middle Paleocene to Early Eocene strata in Belgium and adjacent area. Palaeontographica A 247, 91-156.

Steurbaut, E., De Coninck, J., Dupuis, C., King, C., 2000. Dinoflagellate cyst events and depositional history of the Paleocene/Eocene boundary interval in the southern North Sea Basin. GFF 122, 154-157.

Steurbaut, E., De Coninck, J., Roche, E., Smith, T., 1999. The Dormaal Sands and the Palaeocene/Eocene boundary in Belgium. Bull. Soc. géol. Fr. 170, 217-227.

Steurbaut, E., Magioncalda, R., Dupuis, C., Van Simaeys, S., Roche, E., Roche, M., in press. Palynology, paleoenvironments and organic carbon isotope evolution in lagoonal $\mathrm{Pa}$ leocene/Eocene boundary settings in North Belgium. In: Wing, S.L., et al. (Eds.), Causes and Consequences of Glob- 
ally Warm Climates in the Early Paleogene. Geol. Soc. Am. Spec. Pap. 369.

Stewart, W.N., Rothwell, G.W., 1993. Paleobotany and the Evolution of Plants, 2nd ed. Cambridge University Press, Cambridge.

Stockey, R.A., Rothwell, G.W., Falder, A.B., 2001. Diversity among taxodioid conifers: Metasequoia foxii sp. nov. from the Paleocene of Central Alberta, Canada. Int. J. Plant Sci. $162,221-234$

Stockmans, F., Willière, Y., 1934. Notes sur des bois fossiles récoltés en Belgique. II. Pinuxylon pinastroides Kraus sp. III. Palmoxylon bacillare Brongn. sp. IV. Glyptostroboxylon tenerum Kraus sp. Bull. Mus. r. Hist. nat. Belg. 10, 1-11.

Streel, M., 1965. Techniques de préparation des roches détritiques en vue de l'analyse palynologique quantitative. Ann. Soc. géol. Belg. 88, B107-B117.

Süss, H., Schultka, S., 2001. First record of Glyptostroboxylon from the Upper Jurassic of Tendaguru, Tanzania. Bot. J. Linnean Soc. 135, 421-429.

Süss, H., Velitzelos, E., 1997. Fossile Hölzer der Familie Taxodiaceae aus tertiären Schichten des Versteinerten Waldes von Lesbos, Griechenland. Feddes Repert. 108, 1-30.
Swofford, D.L., 1991. PAUP: Phylogenetic Analysis Using Parsimony. 3.1.1. Natural History Survey, Champaign, IL, pp. 1-263.

Van den Broeck, E., Rutot, A., 1894. Carte Géologique de la Belgique à 1/40.000, Meldert-Tirlemont 104, Institut cartographique militaire.

van der Burgh, J., 1973. Hölzer der niederrheinischen Braunkohlenformation, 2. Hölzer der Braunkohlengruben 'Maria Theresa' zu Herzogenrath, 'Zukunft West' zu Eschweiler und 'Victor' (Zülpich Mitte) zu Zülpich. Nebst einer systematisch-anatomischen Bearbeitung der Gattung Pinus L. Rev. Palaeobot. Palynol. 15, 73-275.

van der Burgh, J., Meijer, J.J.F., 1996. Taxodioxylon gypsaceum and its botanical affinities. Curr. Sci. 75, 373-378.

Weibel, R., 1996. Petrified wood from an unconsolidated sediment, Voervadsbro, Denmark. Sediment. Geol. 101, 31-41.

Yao, X., Taylor, T.N., Taylor, E.D., 1997. A taxodiaceous seed cone from the Triassic of Antarctica. Am. J. Bot. 84, 343-354.

Yao, X., Zhou, Z., Zhang, B., 1998. Reconstruction of the Jurassic conifer Sewardiodendron laxum (Taxodiaceae). Am. J. Bot. 85, 1289-1300. 